\title{
Non-family chair and corporate performance
}

\author{
Fuxiu Jiang, Xiaojia Zheng and Wei Tang*
}

\author{
* Correspondence: \\ tang2066@ruc.edu.cn \\ School of Business, Renmin \\ University of China, 59 \\ Zhongguancun Street, Haidian \\ District, Beijing 100872, China
}

\begin{abstract}
Using a sample of Chinese family firms listed from 1999 to 2014, we investigate the relationship between non-family leadership and firm performance. We find that firms with a non-family member as board chair perform significantly worse than firms whose chair belongs to the family. Moreover, we show that the underperformance of nonfamily-chair firms is more pronounced when firms are under weaker outside monitoring and when the controlling families care less about family business longevity. The negative effect of a non-family chair is robust to a variety of endogeneity tests. We also dismiss alternative explanations other than concern for reputation. Overall, our empirical results suggest that the social norms regarding family reputation are important in shaping the controlling shareholders' expropriation incentives and firm performance.
\end{abstract}

Keywords: Non-family chair, Non-family leadership, Corporate performance, Family firms, Family reputation

JEL classification: G32, G34

"Publicity is justly commended as a remedy for social and industrial diseases. Sunlight is said to be the best of disinfectants; electric light the most efficient policeman."

-Louis D. Brandeis

\section{Introduction}

With the prevalence of family firms around the world (La Porta et al. 1999; Claessens et al. 2000; Morck et al. 2000; Faccio and Lang 2002), an increasing number of studies have shed light on how family firms perform. One dimension that is widely acknowledged is family involvement, which, it has been suggested, overpowers family ownership and the use of control-enhancing mechanisms in influencing firm performance (Villalonga and Amit 2006; Andres 2008). With aligned interests between family managers and family owners and the consequent weaker principal-agent conflicts, firms with family CEOs have been shown to have better performance than those headed by non-family CEOs (e.g., McConaughy et al. 1998; Anderson and Reeb 2003; Maury 2006; Sraer and Thesmar 2007; Andres 2008; Cai et al. 2012; Isakov and Weisskopf 2014). However, given the small talent

(c) The Author(s). 2018 Open Access This article is distributed under the terms of the Creative Commons Attribution 4.0 International License (http://creativecommons.org/licenses/by/4.0/), which permits unrestricted use, distribution, and reproduction in any medium, provided you give appropriate credit to the original author(s) and the source, provide a link to the Creative Commons license, and indicate if changes were made. 
pool among families, family CEOs are inferior in running the business - especially descendant CEOs (Smith and Amoako-Adu 1999; Morck et al. 2000; Burkart et al. 2003; Pérez-González 2006; Villalonga and Amit 2006; Bennedsen et al. 2007; Bertrand et al. 2008; Cucculelli and Micucci 2008; Chang and Shim 2014). Meanwhile, as family CEOs allow family owners to maximize private benefits at the expense of minority shareholders (Young et al. 2008; Jiang and Peng 2011), having a family member as the CEO can be detrimental to firm performance.

Though there are ongoing debates on whether family involvement benefits a firm or destroys firm value, most attention is paid to CEOs while little is known about the effect of the board chair. Board of directors plays a critical role in understanding the impacts of family involvement on firm performance (Zattoni et al. 2015). As the leader of the board, the chair is endowed with substantial power in influencing strategic decisions (Krause et al. 2016) and explains an even larger percentage of performance variance than does the CEO (Krause 2017; Withers and Fitza 2017). Thus, instead of focusing on the CEO, we investigate the role of board chair - the more significant leader. We examine whether and how an unrelated board chair affects firm performance and the conditions under which the costs of appointing a non-family chair may be reduced.

In family firms, reputation capital is highly valued by the controlling families (Berrone et al. 2010; Deephouse and Jaskiewicz 2013; Mullins and Schoar 2016). To build a good family image, family firms are more likely to adopt a strategy of IPO underpricing (Leitterstorf and Rau 2014), provide higher quality accounting information (Martin et al. 2016), and engage in extensive corporate social responsibility (Dyer and Whetten 2006; Berrone et al. 2010). However, the reputation concern is not the same for all family firms (Zellweger et al. 2013; Martin et al. 2016), nor is it the same for firms with family or non-family chairs. The chair is the representative of the firm in charge of communicating with external stakeholders and is often under strong scrutiny from the public (Krause et al. 2016). Having a family member serve as the board chair strengthens the identity overlap between the family and the firm, which induces the family to weigh the costs of reputation loss even though the unfavorable effect is at the firm level. In contrast, when a non-family member is the board chair, the controlling family only has a weak reputation concern as they may partially escape blame for exploitative behaviors (Chen et al. 2015). In non-family-chair firms, the controlling families sit in the shadows. Because of the indirect channel through non-family chairs and the loose ties between the family and the firm, family reputation is only weakly affected - even when the firm suffers from a negative image. The incentive of families to proactively serve in the interests of non-family shareholders is also weak due to the limited impact on the family's reputation. Thus, with lower costs of reputation loss borne by families for self-interested behaviors, firms with family outsiders serving as board chairs may perform worse than family-chair firms.

We test the hypothesis of the non-family-chair effect by using data from China. Compared with developed markets, investor protection in China is quite weak, with major interest conflicts between the controlling shareholder and minority shareholders (Faccio and Lang 2002). Since the leading concern in family firms is expropriation by the family owners, China provides a good setting to examine the effect of family involvement resulting from the principal-agency problem. In addition, the separate board 
structure with the positions of chair and CEO held by two different people is relatively common in Chinese firms compared with firms in countries like the U.S. This allows us to document the chair effect and eliminate the simultaneous CEO effect. The significant impact of the Chinese economy and the superior power endowed to board chairs by China's corporate laws also encourage us to concentrate on China. Furthermore, the core of Chinese commercial practices is "guanxi" for which reputation plays a critical role (Park and Luo 2001). The unique social system and collectivist culture highly values reputation capital and thus makes the costs of reputation loss extremely high for controlling families, which strengthens the role of the board chair.

Using a sample of 1466 non-financial A-share listed firms in China, we find that firms with non-family chairs who have no apparent relationship in blood or marriage with the controlling families perform significantly worse compared to family-chair firms. The negative effects of passive control (i.e., a non-family member being board chair) are reflected in lower accounting performance than firms with active family involvement no matter which performance measure we use. This result is robust to a variety of model specifications and after controlling for potential endogeneity issues using the propensity score matching method, instrumental approaches and a difference-in-difference analysis of chair turnover. We consistently find a negative relation between non-family chair and firm performance.

To verify the argument that controlling families expropriate minority shareholders aggressively when the board chair is appointed outside the family, we further examine the conditions under which the negative effect of a non-family board chair on firm performance is mitigated or worsened. We find that the loss in performance resulting from a non-family appointment is reduced when there is a more developed institutional environment, a higher analyst coverage, more intense scrutiny from the public, stronger monitoring by other large shareholders, or when a firm is controlled by an entrepreneur with multiple children. That is, the negative relationship between the non-family board chair and firm performance is more pronounced when the listed firm is under weak outside monitoring and when the controlling shareholder tends to care less about family business longevity. Those results support the reputation argument - that in cases of weak reputation concern, the incentive of the controlling family to extract private benefits increases and leads to lower performance in non-family-chair firms than in their counterparts. Finally, we show that the documented inferior performance of non-family-chair firms cannot be explained by the talent or agency problem of the $\mathrm{CEO}$, the intensity of family monitoring, the excess control rights held by the families and stock liquidity. The evidence from tests on alternative explanations implies that the negative impact of a non-family board chair on firm performance cannot be dominated by factors other than reputation. Overall, we find that chairs from outside the controlling family are suboptimal to family members in term of firm performance when institutional efficiency is low.

Our paper contributes to the literature that examines the effect of family involvement on family firm performance. The findings on this subject have been mixed. Instead of joining the debate on whether family CEOs purely improve or damage firm performance (e.g., Anderson and Reeb 2003; Maury 2006; Bennedsen et al. 2007; Bertrand et al. 2008; Cai et al. 2012; Isakov and Weisskopf 2014), or how family involvement with strategic control and operational control affects principal-agent conflicts (Luo and Chung 2013), we focus on the unexplored role of the board chair in family firms from the perspective of 
principal-principal conflict and examine the more important question: Under what conditions will the negative impact of a non-family appointment be reduced or reinforced? The various methods we use to address endogeneity concerns further ensure the robustness of our results. The documented differences in performance between firms with family and non-family board chairs also support the argument on the significant heterogeneity among family firms (Chua et al. 2012) and the importance of board in family firms (Zattoni et al. 2015). By showing that having a non-family chair leads to poor firm performance, our paper also contributes to the increasing number of studies which have investigated the role of a board chair in firms' decision making (Ma et al. 2013; Chen et al. 2015; Krause et al. 2016; Krause 2017; Withers and Fitza 2017).

Moreover, this paper provides insight into the role of family involvement in emerging countries. Most family firm studies have been conducted in developed countries (Filatotchev et al. 2005), yet firm characteristics such as ownership structure and the institutional environment in which family firms operate are quite different from those in emerging markets with weak investor protection - which may lead to different conclusions (Miller et al. 2007; Isakov and Weisskopf 2014). Therefore, we extend the work on investigating the effect of family involvement in a specific, important and scarcely explored institutional context: China. We further complement prior papers (e.g., Cai et al. 2012; Amit et al. 2015; Chen et al. 2015; $\mathrm{Xu}$ et al. 2015) by using data from China to show that the appointment of a non-family chair can erode firm performance, and the chair effect may depend on the intensity of interest conflicts between controlling families and the minority shareholders.

Finally, this paper also contributes to the literature that seeks to understand the function of informal institutions (e.g., Putnam 1993; Pamuk 2000). Due to the threat of being excluded from a group if they violate social norms, members' behaviors are partially restricted by moral standards (Elster 1989). Recent studies have indicated that reputation can play a critical role in improving corporate governance with respect to managerial agency problems (e.g., Dyck et al. 2008; Karpoff et al. 2008). By showing that reputation serves as a substitute for weak formal institutions since it inhibits controlling families from expropriating minority shareholders and improves firm performance, our paper complements the previous studies on the reputation effect on a firm.

The rest of the paper is organized as follows. Section "Data" describes the sample selection process and offers summary statistics and the outlines of empirical model. Section "Empirical results" shows the empirical results of the relation between having a non-family chair and firm performance. Section "Endogeneity issues" discusses endogeneity concerns, while Section "Moderating effects of outside monitoring and family structure" explores the conditions under which the non-family chair affects firm performance to different degrees. Section "Alternative explanations" tests alternative explanations and Section "Conclusion" concludes.

\section{Data}

In this section, we present the detailed sample selection procedures, summary statistics and the correlation matrix of the main variables in the regression.

\section{Sources and sample}

Our initial sample consists of all A-share firms listed on the Shanghai and Shenzhen Stock Exchanges between 1999 and 2014. ${ }^{1}$ We extracted information on the ultimate 
controller from the Chinese Securities Market and Accounting Research (CSMAR) database. We then manually verified it with each annual report while deleting firms whose controllers could not be traced to individuals or families. ${ }^{2}$ We further merged the data about the ultimate controllers and chairs with firms' financial data derived from CSMAR. To clarify the relationship between the ultimate controller and board chair in a given firm, we hand-collected relationship and background information (e.g., name, age, education, experience) from prospectuses and annual reports where the listed firms are required to disclose affiliated relationships within the top ten large shareholders; we also searched online to glean this information from news and reports. We referred to the board chair who shares no apparent family connections (e.g., blood ties or marriage relations) with the firm's ultimate controller as a non-family chair; however, if the controller and the chair belong to the same family, we refer to this as a family chair. Due to the uniqueness in accounting standards and performance measures, all financial firms are excluded from our sample. After deleting firm-years with missing information on key variables, our final sample includes 7902 firm-year observations on 1466 firms. To address outliers, all continuous variables are winsorized at the 1st and 99th percentiles.

In our sample, $27.45 \%$ of the firm-year data has a non-family member as the chair of the board of directors, while about $72.55 \%$ of the sample has family chairs including entrepreneurs (66.50\%) and relatives (6.05\%). Panel A of Table 1 further shows the distribution of non-family-chair firms across the sample period. ${ }^{3}$ The percentage of firms with a non-family chair did not vary much before 2008, but it decreased from $34.30 \%$ in 2008 to $21.76 \%$ in $2014 .{ }^{4}$ We assume that the overall downward tendency of non-family appointments is driven by the incoming new and young listed firms. In the robustness test, we reexamine the hypotheses by deleting firms listed on the Small and Medium Enterprise Board and the Chinese Growth Enterprise Market. Panel B illustrates the industry distribution. Firms with a non-family chair are not uniformly distributed within and across industries. For example, 53.19\% of the sample in the energy supply industry have board chairs from outside the family, while the percentage of firm-years is only $16.16 \%$ in the electronics industry. The differences in industry representation suggest that controlling industry is necessary for our analyses.

\section{Model description}

The key variable in this study is the relationship between the identified ultimate controller and the board chair. We define a dummy variable, NFChair, taking a value of one if the chair is not a family member (and 0 otherwise). Following previous research (Bennedsen et al. 2007; Bertrand et al. 2008; Xu et al. 2015), we measure firm performance using return on assets and return on sales, where return is computed using net income or operating income. ${ }^{5}$ These variables are $R O A$ (net income divided by total assets), OROA (operating income divided by total assets), ROS (net income divided by total sales) and OROS (operating income divided by total sales).

In addition to controlling for the non-family-chair indicator, we further control a few variables that have been commonly adopted in studies on firm performance (e.g., Anderson and Reeb 2003; Villalonga and Amit 2006; Fahlenbrach 2009). The first category of control variables includes the logarithm of a firm's market capitalization (Size), the market-to-book ratio of equity $(M B)$ and the ratio of total liability to total assets (Leverage). The board 
Table 1 The number and percentage of firm-year observations by year and industry

\begin{tabular}{|c|c|c|c|c|c|c|}
\hline & \multicolumn{2}{|c|}{ All firms } & \multicolumn{2}{|c|}{ Family-chair firms } & \multicolumn{2}{|c|}{ Non-family-chair firms } \\
\hline & Obs. & $\%$ & Obs. & $\%$ & Obs. & $\%$ \\
\hline \multicolumn{7}{|c|}{ Panel A: Distribution of firm-years by year } \\
\hline \multicolumn{7}{|l|}{ Year } \\
\hline 2000 & 11 & 0.139 & 4 & 36.364 & 7 & 63.636 \\
\hline 2001 & 47 & 0.595 & 30 & 63.830 & 17 & 36.170 \\
\hline 2002 & 94 & 1.190 & 59 & 62.766 & 35 & 37.234 \\
\hline 2003 & 158 & 1.999 & 83 & 52.532 & 75 & 47.468 \\
\hline 2004 & 239 & 3.025 & 128 & 53.556 & 111 & 46.444 \\
\hline 2005 & 269 & 3.404 & 138 & 51.301 & 131 & 48.699 \\
\hline 2006 & 310 & 3.923 & 167 & 53.871 & 143 & 46.129 \\
\hline 2007 & 343 & 4.341 & 197 & 57.434 & 146 & 42.566 \\
\hline 2008 & 484 & 6.125 & 318 & 65.702 & 166 & 34.298 \\
\hline 2009 & 529 & 6.695 & 360 & 68.053 & 169 & 31.947 \\
\hline 2010 & 621 & 7.859 & 446 & 71.820 & 175 & 28.180 \\
\hline 2011 & 923 & 11.681 & 708 & 76.706 & 215 & 23.294 \\
\hline 2012 & 1184 & 14.984 & 958 & 80.912 & 226 & 19.088 \\
\hline 2013 & 1339 & 16.945 & 1080 & 80.657 & 259 & 19.343 \\
\hline 2014 & 1351 & 17.097 & 1057 & 78.238 & 294 & 21.762 \\
\hline Total & 7902 & 100 & 5733 & 72.551 & 2169 & 27.449 \\
\hline \multicolumn{7}{|c|}{ Panel B: Distribution of firm-years by industry } \\
\hline \multicolumn{7}{|l|}{ Industry } \\
\hline Agriculture & 162 & 2.050 & 123 & 75.926 & 39 & 24.074 \\
\hline Mining & 84 & 1.063 & 52 & 61.905 & 32 & 38.095 \\
\hline Food & 307 & 3.885 & 217 & 70.684 & 90 & 29.316 \\
\hline Apparel & 394 & 4.986 & 279 & 70.812 & 115 & 29.188 \\
\hline Furniture & 74 & 0.936 & 58 & 78.378 & 16 & 21.622 \\
\hline Printing & 181 & 2.291 & 147 & 81.215 & 34 & 18.785 \\
\hline Gas and Chemistry & 844 & 10.681 & 598 & 70.853 & 246 & 29.147 \\
\hline Electronics & 495 & 6.264 & 415 & 83.838 & 80 & 16.162 \\
\hline Metal & 547 & 6.922 & 401 & 73.309 & 146 & 26.691 \\
\hline Machinery & 1629 & 20.615 & 1259 & 77.287 & 370 & 22.713 \\
\hline Pharmaceutical Products & 634 & 8.023 & 480 & 75.710 & 154 & 24.290 \\
\hline Other Manufacturing & 107 & 1.354 & 84 & 78.505 & 23 & 21.495 \\
\hline Energy Supply & 47 & 0.595 & 22 & 46.809 & 25 & 53.191 \\
\hline Construction & 164 & 2.075 & 124 & 75.610 & 40 & 24.390 \\
\hline Transportation & 70 & 0.886 & 41 & 58.571 & 29 & 41.429 \\
\hline Information Technology & 759 & 9.605 & 594 & 78.261 & 165 & 21.739 \\
\hline Retail \& Wholesale & 402 & 5.087 & 211 & 52.488 & 191 & 47.512 \\
\hline Real Estate & 427 & 5.404 & 280 & 65.574 & 147 & 34.426 \\
\hline Other Service Supply & 193 & 2.442 & 144 & 74.611 & 49 & 25.389 \\
\hline Entertainment & 58 & 0.734 & 45 & 77.586 & 13 & 22.414 \\
\hline Other & 324 & 4.100 & 159 & 49.074 & 165 & 50.926 \\
\hline Total & 7902 & 100.000 & 5733 & 72.551 & 2169 & 27.449 \\
\hline
\end{tabular}

Panel A presents the distribution of our sample by year. Panel B presents the distribution of our sample by industry based on the official classification issued by the China Securities Regulatory Commission (CSRC). Family-chair firms are defined as firms whose chairs are members of the controlling family including the immediate family and other relatives, while non-family chairs share no family connections such as blood ties or marriage. The sample consists of 7902 firmyears for 1466 A-share nonfinancial firms listed on Shanghai and Shenzhen Stock Exchanges during 1999-2014 
characteristic variables include the natural log of the number of directors (Board), the fraction of independent directors (Independence) and a dummy variable indicating whether the CEO is also the chair (Duality). The control variables concerning the firm's ownership structure are the percentage of shares held by the controller (Top1), the sum of the percentage of shares owned by the second to fifth largest shareholders (Top25), the percentage of shares that institutional investors hold (Institution) and an indicator which equals to 1 if the firm has foreign investors (Foreign) (and 0 otherwise). ${ }^{6}$ Other controls are firm characteristics including the ratio of fixed assets to total assets (Tangibility), the number of years since the founding of the firm (Firm age) and the ratio of capital expenditures to total assets $(C a p E x)$. Meanwhile, we also include industry and year dummies to control for any industrial or economy-wide factor that may affect firm performance.

We examine the impact of chair identity on firm performance using the following regression model:

Firm_Performance $=\alpha+\beta$ NFChair $+\sum \gamma_{\mathrm{i}} \mathrm{X}_{\mathrm{i}}+$ Year dummies + Industry dummies $+\varepsilon$,

where Firm_Performance is measured by each of the performance variables (i.e., $R O A$, $O R O A, R O S, O R O S$ ) and NFChair is a dummy variable indicating a non-family-chair appointment. The variable $X_{i}$ refers to a set of control variables including firm, board and ownership structure characteristics. To mitigate the simultaneous effects, control variables are one-year lagged. Standard errors are robust to heteroskedasticity and clustered at the firm level to account for potential correlations between firms. The coefficient of interest $\beta$ suggests the underperformance of non-family-chair firms with a negative sign (and vice versa).

\section{Summary statistics}

Table 2 reports descriptive statistics for the full sample (Panel A) and the subsamples of firms with and without a non-family chair (Panel B). It shows that firms on average earn $3.6 \%, 3.6 \%, 4.9 \%$ and $3.7 \%$ of $R O A, O R O A, R O S$ and OROS, respectively, during our sample period. Those features are consistent with prior studies using the sample of Chinese non-SOE firms (Liu et al. 2015; Xu et al. 2015). As for firm characteristics, the ratio of leverage is $43.2 \%$ which indicates that our sample firms are highly leveraged and have been in existence for more than 11 years. The mean (median) number of directors on a board is 8.4 (9) with $35.9 \%$ independent directors ${ }^{7}$; for about $30.2 \%$ of the firm-years, the chair also serves as CEO. Regarding the ownership structure, the percentage of shares held by the largest shareholder in our sample firms is on average $33.4 \%$; and the percentage at the first (last) quartile is $22.56 \%(42.54 \%)$. The sum of shares owned by the second to fifth largest shareholders is $20.42 \%$, which indicates a common concentrated ownership structure in Chinese firms as well as the strong power of the controlling shareholder to expropriate minority shareholders. Unlike developed countries, in China, institutional investors hold only a small number of shares (4.4\%). Meanwhile, just 3.1\% of our sample firms have foreign investors.

In Panel B of Table 2, significant differences between firms with a family or a non-family chair are apparent. We test the equality of the means using T-tests and the median using a Wilcoxon rank sum test. On average, firms with non-family chairs underperform those firms headed by entrepreneurs or their relatives in all four 
Table 2 Summary statistics

Panel A: Summary statistics

Variable Obs.

A. Firm performance

$\begin{array}{lllllll}\text { ROA } & 7902 & 0.036 & 0.078 & 0.014 & 0.038 & 0.068 \\ \text { OROA } & 7902 & 0.036 & 0.081 & 0.011 & 0.039 & 0.073 \\ \text { ROS } & 7886 & 0.049 & 0.352 & 0.025 & 0.070 & 0.138 \\ \text { OROS } & 7886 & 0.037 & 0.373 & 0.021 & 0.071 & 0.148\end{array}$

B. Firm characteristics

$\begin{array}{lllllll}\text { Size } & 7902 & 21.350 & 0.883 & 20.770 & 21.280 & 21.890 \\ \text { MB } & 7902 & 2.701 & 2.852 & 1.400 & 1.887 & 2.993 \\ \text { Leverage } & 7902 & 0.432 & 0.319 & 0.224 & 0.408 & 0.578 \\ \text { Tangibility } & 7902 & 0.212 & 0.148 & 0.097 & 0.186 & 0.300 \\ \text { Firm age } & 7902 & 11.540 & 5.246 & 8 & 11 & 15 \\ \text { CapEx } & 7902 & 0.059 & 0.062 & 0.015 & 0.044 & 0.088\end{array}$

C. Board characteristics

$\begin{array}{lllllll}\text { NFChair } & 7902 & 0.274 & 0.446 & 0 & 0 & 1 \\ \text { Board } & 7902 & 2.134 & 0.194 & 1.946 & 2.197 & 2.197 \\ \text { Independence } & 7902 & 0.359 & 0.071 & 0.333 & 0.333 & 0.400 \\ \text { Duality } & 7902 & 0.302 & 0.459 & 0 & 0 & 1\end{array}$

D. Ownership structure

$\begin{array}{lllllll}\text { Top1 } & 7902 & 33.400 & 14.310 & 22.560 & 30.040 & 42.540 \\ \text { Top25 } & 7902 & 20.420 & 11.650 & 11.190 & 19.370 & 28.670 \\ \text { Institution } & 7902 & 0.044 & 5.832 & 0 & 1.915 & 6.677 \\ \text { Foreign } & 7902 & 0.031 & 0.173 & 0 & 0 & 0\end{array}$

Panel B: Firm performance of the subsample firms

\begin{tabular}{|c|c|c|c|c|c|c|}
\hline \multirow[b]{2}{*}{ Variable } & \multicolumn{2}{|c|}{ Non-family-chair firms (Obs. $=2169)$} & \multicolumn{2}{|c|}{ Family-chair firms (Obs. = 5733) } & \multicolumn{2}{|l|}{ Difference } \\
\hline & Mean & Median & Mean & Median & Mean & Median \\
\hline $\mathrm{ROA}$ & 0.015 & 0.026 & 0.043 & 0.042 & $-0.028^{* * *}$ & $-0.016^{* * *}$ \\
\hline OROA & 0.013 & 0.026 & 0.045 & 0.044 & $-0.033^{* * *}$ & $-0.018^{* * *}$ \\
\hline ROS & -0.025 & 0.048 & 0.077 & 0.079 & $-0.102^{* * *}$ & $-0.031^{* * *}$ \\
\hline OROS & -0.052 & 0.047 & 0.070 & 0.080 & $-0.122^{* * *}$ & $-0.033^{* * *}$ \\
\hline
\end{tabular}

Panel A presents the summary statistics of firm characteristics including firm performance, ownership, board and other characteristics for the full sample. The sample consists of 7902 firm-years for 1466 A-share nonfinancial firms listed on the Shanghai and Shenzhen Stock Exchanges during 1999-2014. See the Appendix for the detailed definitions of the variables. Panel B presents the performance difference between non-family-chair firms and family-chair firms, and the last two columns show the significance of the differences in mean from a mean-comparison test and the median based on a nonparametric Wilcoxon test. Significance at the $1 \%\left({ }^{* *}\right), 5 \%(* *)$ or $10 \%(*)$ level is indicated

performance measures. For example, the mean and median of $R O A$ for non-family-chair firms are, respectively, $1.5 \%$ and $2.6 \%$, while the corresponding performances of family-chair firms are much higher at $4.3 \%$ and $4.2 \%$. The differences in performance between these two groups are all highly significant at the $1 \%$ level.

\section{Correlation matrix}

In Table 3, we present the correlations between our dependent variables (ROA, OROA, $R O S$ and OROS) and other variables of interest. The correlation matrix shows that 


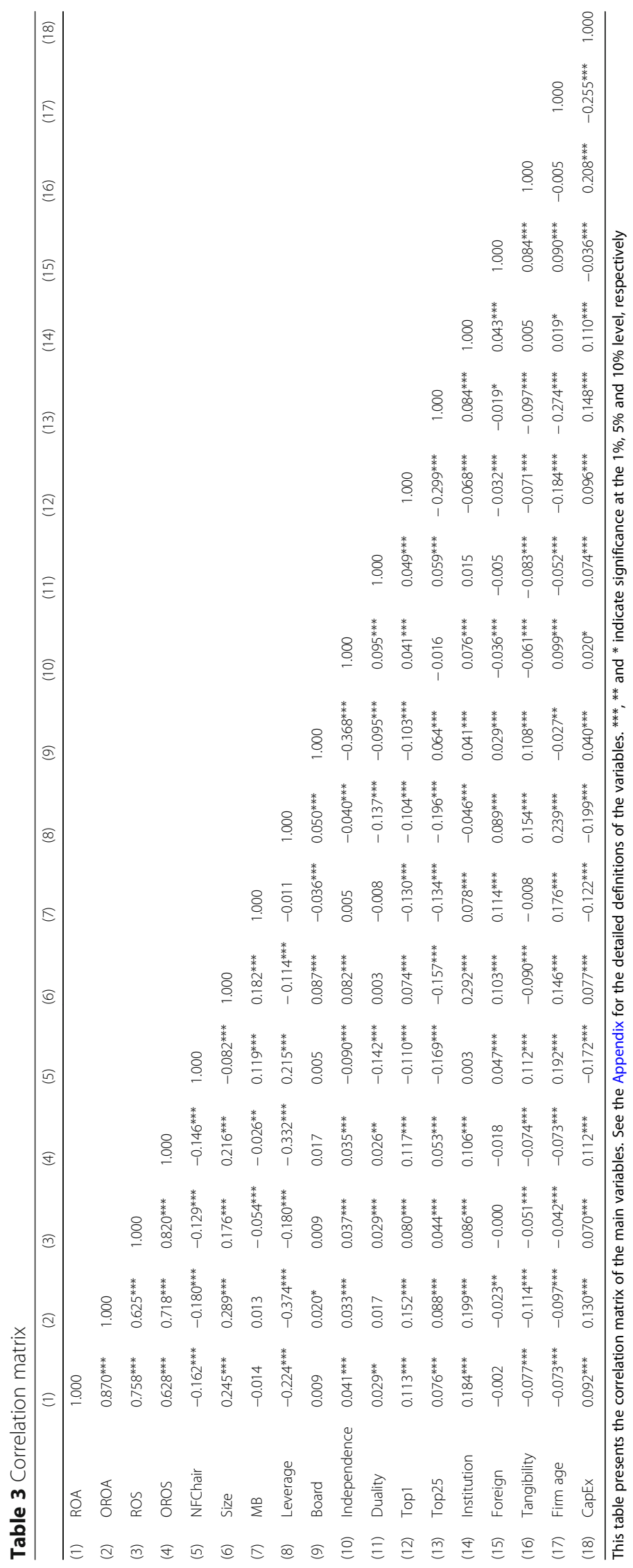


except for the correlations between different performance measures, there is no correlation higher (lower) than $0.4(-0.4),{ }^{8}$ indicating that multicollinearity is not a serious problem in this study. Meanwhile, we find that the correlation between performance measures and the indicator of a chair's non-family identity (NFChair) are all significantly negative, ranging from -0.180 to -0.129 .

\section{Empirical results}

In this section, we present the main empirical results from the OLS regression model and perform a few additional tests to further verify our findings.

\section{Main results}

Table 4 shows the results of the main OLS regression model. In columns 1 and 3, we report the estimates on the non-family chair dummy in the specification with $R O A$ and $O R O A$ as the dependent variables without any control except industry and year dummies. The coefficients of the non-family chair dummy are significantly negative, which suggests that firms with non-family chairs have on average $2.3 \%$ (2.9\%) lower ROA (OROA) compared with firms headed by entrepreneurs or their relatives without the consideration of other differences between these two groups of firms. In columns 2 and 4, we add a few control variables concerning firm, board and ownership structure characteristics in the regression. The coefficient estimates on the non-family chair dummy both remain statistically significant at the $1 \%$ level and negative, though the sizes decrease to $1.4 \%$ and $1.5 \%$ for $R O A$ and $O R O A$ respectively. Given that the mean return on assets is $3.6 \%$, the effect of a chair's non-family identity on firm performance is economically significant. With regard to return on sales, we present the results in columns 5 to 8 using similar regression models. The estimates have the same sign and a similar size at 0.048 across the specifications after controlling abundant variables indicating potential differences. We conclude that non-family-chair firms perform worse than those with family members as chair, regardless of how firm performance is measured.

The rest of the coefficient estimates on control variables have the expected signs and significances. The coefficient of firm size is significant and positive in all four regressions, which is consistent with the logic that larger firms outperform smaller firms due to privileges such as the availability of low-cost capital. The regression results show that firm performance decreases with firm leverage, which is also found in other studies. With regard to ownership structure, the coefficients of the shares held by the largest shareholder (Top1) are significantly positive, indicating that firms benefit from an appropriate concentrated ownership structure. Meanwhile, other large shareholders and institutional investors contribute to firm performance suggested by the positive signs of coefficients on shares owned by the second to fifth largest shareholder (Top25) and institutional ownership (Institution). Consistent with the literature on firm performance using Chinese listed firms, most of the variables regarding board characteristics are not distinguishable from zero. The ineffectiveness of internal corporate governance mechanisms thus suggests the demand for efficient external governance. In addition, firm performance - measured by operating incomes - increases with firm investments, while investments have no critical impact on net-income firm performance measures. In 
Table 4 Ordinary least square (OLS) regressions of firm performance

\begin{tabular}{|c|c|c|c|c|c|c|c|c|}
\hline & \multicolumn{2}{|l|}{$\mathrm{ROA}$} & \multicolumn{2}{|l|}{ OROA } & \multicolumn{2}{|l|}{ ROS } & \multicolumn{2}{|l|}{ OROS } \\
\hline & (1) & (2) & (3) & (4) & (5) & (6) & (7) & (8) \\
\hline \multirow[t]{2}{*}{ NFChair } & $-0.023^{* * *}$ & $\overline{-} .014^{* * *}$ & $\overline{-} .029^{* * *}$ & $-\overline{0.015^{* * *}}$ & $\overline{-} .083^{* * *}$ & $\overline{-} .048^{* * *}$ & $-\overline{0.104^{* * *}}$ & $\overline{-} .048^{* * *}$ \\
\hline & $(-7.41)$ & $(-4.93)$ & $(-7.66)$ & $(-5.03)$ & $(-5.96)$ & $(-3.65)$ & $(-6.39)$ & $(-3.49)$ \\
\hline \multirow[t]{2}{*}{ Size } & & $0.016^{* * *}$ & & $0.021^{* * *}$ & & $0.049^{* * *}$ & & $0.070^{* * *}$ \\
\hline & & (10.66) & & (13.17) & & $(7.97)$ & & $(9.55)$ \\
\hline \multirow[t]{2}{*}{ Leverage } & & $-0.037^{* * *}$ & & $-0.081^{* * *}$ & & $\overline{-} .159^{* * *}$ & & $\overline{-} .373^{* * *}$ \\
\hline & & $(-4.38)$ & & $(-11.50)$ & & $(-3.13)$ & & $(-7.38)$ \\
\hline \multirow[t]{2}{*}{ MB } & & -0.001 & & -0.000 & & $-0.009^{* * *}$ & & -0.004 \\
\hline & & $(-1.39)$ & & $(-0.05)$ & & $(-2.68)$ & & $(-1.32)$ \\
\hline \multirow[t]{2}{*}{ Board } & & 0.000 & & 0.003 & & 0.026 & & 0.047 \\
\hline & & $(0.07)$ & & $(0.53)$ & & $(0.86)$ & & $(1.29)$ \\
\hline \multirow[t]{2}{*}{ Independence } & & -0.014 & & -0.014 & & 0.003 & & 0.035 \\
\hline & & $(-0.61)$ & & $(-0.63)$ & & $(0.03)$ & & $(0.31)$ \\
\hline \multirow[t]{2}{*}{ Duality } & & -0.003 & & $-0.006^{* * *}$ & & -0.009 & & $-0.019^{*}$ \\
\hline & & $(-1.50)$ & & $(-2.61)$ & & $(-0.90)$ & & $(-1.77)$ \\
\hline \multirow[t]{2}{*}{ Top1 } & & $0.001^{* * *}$ & & $0.001^{* * *}$ & & $0.002^{* * *}$ & & $0.002^{* * *}$ \\
\hline & & (7.11) & & $(8.60)$ & & $(4.66)$ & & $(5.92)$ \\
\hline \multirow[t]{2}{*}{ Top25 } & & $0.001^{* * *}$ & & $0.001^{* * *}$ & & $0.001^{* * *}$ & & $0.001^{* *}$ \\
\hline & & $(5.21)$ & & $(5.52)$ & & $(2.91)$ & & $(2.05)$ \\
\hline \multirow[t]{2}{*}{ Institution } & & $0.002^{* * *}$ & & $0.002^{* * *}$ & & $0.003^{* * *}$ & & $0.003^{* * *}$ \\
\hline & & $(8.21)$ & & $(7.61)$ & & (3.69) & & $(4.10)$ \\
\hline \multirow[t]{2}{*}{ Foreign } & & 0.002 & & -0.007 & & 0.035 & & 0.000 \\
\hline & & $(0.25)$ & & $(-0.77)$ & & $(0.79)$ & & $(0.01)$ \\
\hline \multirow[t]{2}{*}{ Tangibility } & & -0.005 & & $-0.022^{* *}$ & & 0.050 & & 0.033 \\
\hline & & $(-0.58)$ & & $(-2.29)$ & & $(1.17)$ & & $(0.71)$ \\
\hline \multirow[t]{2}{*}{ Firm age } & & -0.000 & & 0.000 & & -0.001 & & -0.000 \\
\hline & & $(-0.94)$ & & $(0.19)$ & & $(-0.97)$ & & $(-0.35)$ \\
\hline \multirow[t]{2}{*}{ CapEx } & & 0.012 & & $0.043^{* *}$ & & 0.056 & & $0.177^{* *}$ \\
\hline & & $(0.72)$ & & $(2.47)$ & & $(0.73)$ & & $(2.10)$ \\
\hline \multirow[t]{2}{*}{ Intercept } & $0.041^{* * *}$ & $-0.304^{* * *}$ & $0.041^{* * *}$ & $-0.411^{* * *}$ & $0.170^{* * *}$ & $-0.927^{* * *}$ & $0.156^{* * *}$ & $-1.348^{* * *}$ \\
\hline & $(3.20)$ & $(-8.80)$ & (2.78) & $(-11.00)$ & $(3.06)$ & $(-6.69)$ & $(2.61)$ & $(-7.98)$ \\
\hline $\begin{array}{l}\text { Industry fixed } \\
\text { effects }\end{array}$ & Yes & Yes & Yes & Yes & Yes & Yes & Yes & Yes \\
\hline Year fixed effects & Yes & Yes & Yes & Yes & Yes & Yes & Yes & Yes \\
\hline Obs. & 7902 & 7902 & 7902 & 7902 & 7886 & 7886 & 7886 & 7886 \\
\hline Adjusted $R^{2}$ & 0.075 & 0.169 & 0.067 & 0.271 & 0.053 & 0.099 & 0.044 & 0.173 \\
\hline
\end{tabular}

This table presents the regression results of firm performance on the indicator of a non-family chair. In columns $1-2$ and $3-4$, we use measures of a return on assets including net income on assets $(R O A)$ and operating income on assets $(O R O A)$ as the dependent variables. In columns 5-6 and 7-8, the dependent variables are return on sales including net income on sales (ROS) and operating income on sales (OROS). All regressions include year and industry dummies, but their coefficients are not reported for the sake of brevity. See the Appendix for detailed descriptions of the variables. The values in parentheses are standard errors that are robust to heteroskedasticity and clustered at the firm level. Asterisks denote statistical significance at the $1 \%\left(^{* *}\right), 5 \%\left(^{* *}\right)$ or $10 \%\left(^{*}\right)$ level, respectively 
sum, the results in Table 4 show that the appointment of a non-family chair deteriorates firm performance.

\section{Robustness checks}

To further verify that firms with a non-family chair underperform firms with a family chair, we conduct several robustness tests concerning alternative variable measures, adding more controls and using subsamples. For the sake of brevity, we only report the results using $R O A$ as the dependent variable in Table $5 .{ }^{9}$ We reestimate the effects of a non-family chair on firm operation by using alternative measures of dependent and independent variables. Specifically, we first use industry-adjusted firm performance measures as the dependent variables to exclude performance variation across industries. Since family involvement of the CEO might also affect firm performance, we include an additional control indicating whether the CEO is a non-family member. In addition, we control for the demographic characteristics of the chair. We repeat the regressions using various subsamples. As information about the ultimate controller was not formally disclosed until 2004, we reestimate the impact of a chair's family identity using the subsample after 2003 to exclude the possibility of identification mistakes in the early years. Moreover, we examine the main regression model by restricting our sample to only firms listed on the main boards due to sample selection concerns. Throughout

Table 5 Robustness checks on the value effects of non-family chair

\begin{tabular}{|c|c|c|c|c|c|}
\hline & $\begin{array}{l}\text { Industry-adjusted } \\
\text { measure }\end{array}$ & $\begin{array}{l}\text { Non-family } \\
\text { CEO }\end{array}$ & $\begin{array}{l}\text { Chair } \\
\text { characteristics }\end{array}$ & $\begin{array}{l}\text { Obs. after } \\
2003\end{array}$ & $\begin{array}{l}\text { Obs. of main } \\
\text { boards }\end{array}$ \\
\hline & (1) & (2) & (3) & (4) & (5) \\
\hline \multirow[t]{2}{*}{ NFChair } & $-0.014^{* * *}$ & $-0.013^{* * *}$ & $-0.013^{* * *}$ & $-0.014^{* * *}$ & $-0.014^{* * *}$ \\
\hline & $(-5.09)$ & $(-4.60)$ & $(-4.83)$ & $(-5.02)$ & $(-4.22)$ \\
\hline \multirow[t]{2}{*}{ NFCEO } & & -0.003 & & & \\
\hline & & $(-1.15)$ & & & \\
\hline \multirow[t]{2}{*}{ Chair_Age } & & & 0.008 & & \\
\hline & & & (1.10) & & \\
\hline \multirow[t]{2}{*}{ Chair_Education } & & & 0.001 & & \\
\hline & & & $(0.97)$ & & \\
\hline \multirow[t]{2}{*}{ Chair_Gender } & & & 0.005 & & \\
\hline & & & (1.18) & & \\
\hline \multirow[t]{2}{*}{ Intercept } & $-0.338^{* * *}$ & $-0.300^{* * *}$ & $-0.335^{* * *}$ & $-0.375^{* * *}$ & $-0.353^{* * *}$ \\
\hline & $(-9.79)$ & $(-8.67)$ & $(-7.37)$ & $(-10.35)$ & $(-6.63)$ \\
\hline Other controls & Yes & Yes & Yes & Yes & Yes \\
\hline Industry fixed effects & Yes & Yes & Yes & Yes & Yes \\
\hline Year fixed effects & Yes & Yes & Yes & Yes & Yes \\
\hline Obs. & 7902 & 7895 & 7892 & 7592 & 4058 \\
\hline Adjusted $R^{2}$ & 0.138 & 0.168 & 0.169 & 0.171 & 0.139 \\
\hline
\end{tabular}

This table reports the regression results of firm performance $(R O A)$ on the non-family chair indicator using an alternative measure of the dependent variable, control variable and subsample firms. Column 1 estimates the regression with the industry-adjusted performance measure. Columns 2 and 3 include the additional controls of the CEO's family identity and chair characteristics, respectively. Columns 4 and 5 reflect results when we use data after 2003 and include only firms on the main boards of the Shanghai and Shenzhen Stock Exchanges. All regressions include year and industry dummies, but their coefficients are not reported for the sake of brevity. See the Appendix for the detailed descriptions of the variables. The values in parentheses are standard errors that are robust to heteroskedasticity and clustered at the firm level. Asterisks denote statistical significance at the $1 \%\left(^{* * *}\right), 5 \%\left({ }^{* *}\right)$ or $10 \%\left({ }^{*}\right)$ level, respectively 
the specifications in Table 5, the coefficients on the non-family chair dummy are consistently negative and significant at the $1 \%$ level. In the untabulated test, we also examine the role of a non-family chair using the sample of firms with separate positions for the chair and CEO and again find the significantly negative impact of a non-family chair, while the coefficient of a non-family CEO is insignificant. Hence, the results are qualitatively unchanged regardless of variable measures, controls and samples. The finding of inferior performance of non-family-chair firms is quite robust.

\section{Endogeneity issues}

As illustrated in previous research on CEOs, endogeneity concerns arise when we analyze the effects of family involvement on firm performance (e.g., Bennedsen et al. 2007; Cucculelli and Micucci 2008; Fahlenbrach 2009). The primary concern is reversal causality. The anticipation of bad firm performance might increase the likelihood of the nomination of non-family chairs since the controlling families would like to protect family reputation. Another concern is omitted variables as the time-invariant firm characteristics - such as business culture - might drive our results. In this section, we conduct several tests to address the potential endogeneity between having a non-family chair and firm performance.

\section{The propensity score matching method}

Since the choice of a non-family chair might not be random, we first employ propensity score matching (PSM) to mitigate the endogeneity problem (Rosenbaum and Rubin 1983; Imbens and Wooldridge 2009). This matching procedure provides a reliable control group of firms that are headed by a family member but have a similar possibility of appointing a non-family chair. By comparing firm performance between non-family-chair firms and the corresponding matched family-chair firms with similar characteristics, we hope to identify the effects of chair identity on firm performance without consideration of differences in other dimensions.

The set of variables used to calculate the propensity score in the Probit model include firm size, leverage, market-to-book ratio, and controls concerning corporate governance, ownership structure and other firm characteristics. We also consider industry and year. Because no single matching methodology is perfect, we use various matching methods to check the accuracy of our findings. Consistent with prior studies (e.g., Bae et al. 2011; Jameson et al. 2014), the matching approaches in this paper are: nearest neighborhood matching, Gaussian kernel matching, radius matching and matching with local linear regression. We also use bootstrapped standard errors based on 50 and 100 replications. The statistic of interest in the PSM approach is the average treatment effect on the treated (ATT) which denotes the average difference in firm performance of the treated (non-family-chair firms) relative to the matched control group (family-chair firms).

Table 6 presents the performance gaps using various matching methods. In the nearest-neighborhood matching, the $R O A$ of the treatment firms (non-family-chair firms) averaged is 0.0152 , compared with 0.0306 for corresponding family-chair firms. The mean underperformance of non-family-chair firms, suggested by the negative ATT of -0.0154 , is highly significant given the $t$-statistic of -5.236 . To confirm that our 
Table 6 Tests of performance difference using the propensity score matching method

\begin{tabular}{llll}
\hline Matching method & PSM & Bootstrap (50) & Bootstrap (100) \\
\hline Nearest neighborhood & $-0.0154^{* * *}$ & $-0.0154^{* * *}$ & $-0.0154^{* * *}$ \\
& $(-5.24)$ & $(-5.23)$ & $(-4.19)$ \\
Gaussian kernel & {$[0.97]$} & {$[0.00]$} & {$[0.00]$} \\
& $-0.0154^{* * *}$ & $-0.0154^{* * *}$ & $-0.0154^{* * *}$ \\
& $(-6.08)$ & $(-5.28)$ & $(-5.71)$ \\
Radius caliper matching & {$[1.00]$} & {$[0.00]$} & {$[0.00]$} \\
& $-0.0147^{* * *}$ & $-0.0147^{* * *}$ & $-0.0147^{* * *}$ \\
& $(-4.92)$ & $(-3.19)$ & $(-3.74)$ \\
Local linear regression & {$[0.81]$} & {$[0.00]$} & {$[0.00]$} \\
& $-0.0149^{* * *}$ & $-0.0149^{* * *}$ & $-0.0149^{* * *}$ \\
& $(-4.46)$ & $(-6.41)$ & $(-5.34)$ \\
\hline
\end{tabular}

This table presents the tests of differences in performance between non-family-chair firms and the corresponding matched family-chair firms. We match each non-family-chair firm with a family-chair firm using the one or two nearest neighborhood matching, Gaussian kernel matching, radius matching with a caliper of 0.0001 and matching with local linear regression. The variables in matching are the same as those in the main regression, including firm size, market-tobook ratio, leverage, tangibility, firm age, capital expenditure and a set of board and ownership characteristics. Year and industry dummies are also included. Column 1 reports the average treatment effects on the treated (ATT) for various matching processes when the treated group is non-family-chair firms. Columns 2 and 3 show the results when we use bootstrapped standard errors based on 50 and 100 replications. The t-statistics are in parentheses. Values in brackets are $p$-values for balancing tests in column 1 and for t-statistics in columns 2 and 3 . Asterisks denote statistical significance at the $1 \%\left({ }^{* *}\right), 5 \%\left({ }^{* *}\right)$ or $10 \%\left({ }^{*}\right)$ level, respectively

matching firms are not statistically and comprehensively distinguishable from the treated sample, we conduct additional tests of the balancing assumption. The large size of the $p$-value (0.971) and the small $R^{2}(0.005)$ of the specification where the non-family-chair dummy is regressed on matching variables support the balancing hypothesis. Using bootstrapped standard errors which increase the quality of matching, we also find that the non-family-chair firms maintain a consistently lower $R O A$ than family-chair firms. The results are qualitatively the same in ATTs and balancing tests when we use other matching methodologies. In short, the appointment of a non-family chair generates the performance differences between non-family-chair firms and family-chair firms rather than other firm characteristics.

\section{Instrumental analyses}

To further mitigate the concern of self-selection, we use two instrumental variable methods: the developed Heckman treatment effect model with an endogenous dummy variable (Heckman 1979) and a standard two-stage least squares (2SLS) model (Wooldridge 2002). Instead of using instruments at the firm or industry level, we employ various aspects of province characteristics since they are relatively exogenous for firm performance. $^{10}$ Those instruments are: (1) family ties (Divorce rate), defined as the yearly number of divorce registrations per 10,000 people in the province where a family firm is located; (2) social intensity (Meal income), measured as the logarithm of the total meal income of catering firms at the province level.

We assume that those instruments would be valid for non-family-chair appointments as they are related to the choice of board chair (the relevance condition), but they do not have direct effects on firm performance (the exclusion condition). First, the 
closeness of family ties affects the willingness of a family member to sit on the board. Perceived importance of family is often formed by local attitudes (Rentfrow 2014) and has been stronger in regions with higher marriage rates (Chahine and Goergen 2013). So, we predict that the choice of a non-family chair would be more likely in regions where divorce is more common. However, the regional divorce rate is unlikely to directly affect corporate performance. Second, communication around the dinner table is an important way to build relationships in the traditional socialization culture in China - especially among business partners. Therefore, in regions with a stronger tradition of sharing meals, the controlling families would have more social capital. The extensive social networks encourage family succession with substantial benefits (Xu et al. 2015), which predicts a negative relationship between social intensity and a non-family-chair appointment. Also, it is unlikely that the regional meal income mostly from private firms would have a direct impact on the performance of public firms other than through the appointment of non-family-chairs.

Consistent with previous research (e.g., Villalonga and Amit 2006; Fahlenbrach 2009; Luo and Chung 2013), we conduct a Heckman two-step model using the instruments mentioned. We perform the Probit model in the first stage by using the non-family-chair dummy as the dependent variable, and the explanatory variables include the instruments and other controls as shown in Table 4. We then exclude instruments from the second-stage regressions, but we add the inverse Mills ratio obtained from the first-stage regression as the additional independent variable. Results of the endogenous treatment effect model are reported in Table 7. As expected, the coefficient of Divorce rate is positive, while that of Meal income is negative; both are significant at the $1 \%$ level. That is, non-family members are more likely to be the chair in firms located in regions with loose family and social ties. The significance of the coefficients of the inverse Mills ratio (Lambda) in the second stage confirms the endogeneity concern. Consistent with the results in Table 4, the estimates of the non-family-chair dummy are all negative and significant throughout the specifications. As shown in column 6, the $R O A$ in non-family-chair firms is on average 0.062 lower than in family-chair firms. The two-step procedure of the Heckman model sustains the causation running from the non-family chair to firm performance.

Furthermore, following other studies such as Fahlenbrach (2009) and Xu et al. (2015), we run 2SLS regressions with the instruments used in Table 7. In the first stage, the non-family-chair dummy is regressed on the instruments and other controls from Table 4. We repeat the main regression in the second stage, but we replace the chair dummy with its predicted value instrumented by exogenous variables in the first stage. Results from the 2SLS regressions are shown in Table 8. The coefficients of the instruments are consistent with our expectations, and the tests regarding the weakness of instruments confirm the power of our instruments with all $F$-statistics higher than 10 . The overidentification test also supports the validity of our instruments, which is reflected by the lack of significance of the Sargan chi-squared statistics. Aligned with the results in Table 4, the estimates of the predicted non-family-chair dummy are all significantly negative regardless of the instruments we use. More importantly, the coefficients on the chair dummy are larger in magnitude in the instrumental variables (IV) regressions (-0.062 and -0.068 , respectively, for the treatment effect or 2SLS model) compared with the OLS regressions $(-0.014)$, which increase the plausibility of accounting for 
Table 7 Heckman treatment effect regressions for firm performance and chair identity

\begin{tabular}{|c|c|c|c|c|c|c|}
\hline & \multicolumn{2}{|l|}{ (1) } & \multicolumn{2}{|l|}{ (2) } & \multicolumn{2}{|l|}{ (3) } \\
\hline & First & Second & First & Second & First & Second \\
\hline \multirow[t]{2}{*}{ NFChair } & & $-0.054^{* * *}$ & & $-0.066^{* * *}$ & & $-0.062^{* * *}$ \\
\hline & & $(-3.11)$ & & $(-3.56)$ & & $(-3.78)$ \\
\hline \multirow[t]{2}{*}{ Lambda } & & $0.024^{* *}$ & & $0.031^{* * *}$ & & $0.028^{* * *}$ \\
\hline & & (2.39) & & (2.86) & & $(3.01)$ \\
\hline \multirow[t]{2}{*}{ Size } & -0.025 & $0.015^{* * *}$ & -0.004 & $0.016^{* * *}$ & -0.013 & $0.016^{* * *}$ \\
\hline & $(-1.02)$ & $(10.24)$ & $(-0.15)$ & (10.16) & $(-0.53)$ & (10.19) \\
\hline \multirow[t]{2}{*}{ Leverage } & $0.319^{* * *}$ & $-0.033^{* * *}$ & $0.288^{* * *}$ & $-0.032^{* * *}$ & $0.294^{* * *}$ & $-0.032^{* * *}$ \\
\hline & (5.89) & $(-3.86)$ & (5.30) & $(-3.72)$ & (5.40) & $(-3.79)$ \\
\hline \multirow[t]{2}{*}{ MB } & $0.036^{* * *}$ & -0.000 & $0.034^{* * *}$ & -0.000 & $0.033^{* * *}$ & -0.000 \\
\hline & (6.38) & $(-0.52)$ & (5.86) & $(-0.40)$ & (5.74) & $(-0.49)$ \\
\hline \multirow[t]{2}{*}{ Board } & $-0.357^{* * *}$ & -0.004 & $-0.398^{* * *}$ & -0.008 & $-0.378^{* * *}$ & -0.007 \\
\hline & $(-3.70)$ & $(-0.67)$ & $(-3.90)$ & $(-1.09)$ & $(-3.69)$ & $(-1.02)$ \\
\hline \multirow[t]{2}{*}{ Independence } & $-1.598^{* * *}$ & -0.032 & $-1.975^{* * *}$ & $-0.048^{*}$ & $-1.896^{* * *}$ & $-0.046^{*}$ \\
\hline & $(-4.59)$ & $(-1.38)$ & $(-5.13)$ & $(-1.87)$ & $(-4.91)$ & $(-1.77)$ \\
\hline \multirow[t]{2}{*}{ Duality } & $-0.269^{* * *}$ & $-0.006^{* *}$ & $-0.244^{* * *}$ & $-0.006^{* * *}$ & $-0.245^{* * *}$ & $-0.006^{* *}$ \\
\hline & $(-6.91)$ & $(-2.46)$ & $(-6.14)$ & $(-2.61)$ & $(-6.15)$ & $(-2.54)$ \\
\hline \multirow[t]{2}{*}{ Top1 } & $-0.008^{* * *}$ & $0.001^{* * *}$ & $-0.008^{* * *}$ & $0.000^{* * *}$ & $-0.008^{* * *}$ & $0.001^{* * *}$ \\
\hline & $(-6.17)$ & (5.83) & $(-5.74)$ & $(5.06)$ & $(-5.79)$ & (5.51) \\
\hline \multirow[t]{2}{*}{ Top25 } & $-0.016^{* * *}$ & $0.000^{* * *}$ & $-0.015^{* * *}$ & $0.000^{* *}$ & $-0.015^{* * *}$ & $0.000^{* * *}$ \\
\hline & $(-9.20)$ & (3.14) & $(-8.63)$ & $(2.57)$ & $(-8.36)$ & (2.92) \\
\hline \multirow[t]{2}{*}{ Institution } & $0.010^{* * *}$ & $0.002^{* * *}$ & $0.009^{* * *}$ & $0.002^{* * *}$ & $0.009 * * *$ & $0.002^{* * *}$ \\
\hline & (3.29) & (8.62) & (3.13) & (8.58) & (3.08) & (8.65) \\
\hline \multirow[t]{2}{*}{ Foreign } & -0.068 & 0.001 & 0.045 & 0.001 & 0.040 & 0.001 \\
\hline & $(-0.73)$ & $(0.18)$ & $(0.46)$ & $(0.13)$ & $(0.41)$ & $(0.13)$ \\
\hline \multirow[t]{2}{*}{ Tangibility } & $0.500^{* * *}$ & 0.001 & $0.485^{* * *}$ & 0.001 & $0.454^{* * *}$ & 0.001 \\
\hline & (3.90) & $(0.10)$ & (3.68) & $(0.14)$ & (3.43) & $(0.07)$ \\
\hline \multirow[t]{2}{*}{ Firm age } & $0.035^{* * *}$ & 0.000 & $0.036^{* * *}$ & 0.000 & $0.035^{* * *}$ & 0.000 \\
\hline & (8.85) & $(0.64)$ & (8.95) & $(1.07)$ & (8.76) & $(0.95)$ \\
\hline \multirow[t]{2}{*}{ CapEx } & $-2.191^{* * *}$ & -0.013 & $-2.344^{* * *}$ & -0.030 & $-2.357^{* * *}$ & -0.027 \\
\hline & $(-7.14)$ & $(-0.71)$ & $(-7.36)$ & $(-1.51)$ & $(-7.36)$ & $(-1.42)$ \\
\hline
\end{tabular}

Instrumental variables

\begin{tabular}{|c|c|c|c|c|c|c|}
\hline \multirow[t]{2}{*}{ Divorce rate } & \multicolumn{4}{|l|}{$0.021^{* * *}$} & \multicolumn{2}{|l|}{$0.017^{* * *}$} \\
\hline & \multicolumn{4}{|l|}{$(8.62)$} & \multicolumn{2}{|l|}{$(6.80)$} \\
\hline \multirow[t]{2}{*}{ Meal income } & & & \multicolumn{2}{|l|}{$-0.116^{* * *}$} & \multicolumn{2}{|l|}{$-0.097^{* * *}$} \\
\hline & & & \multicolumn{2}{|l|}{$(-7.68)$} & \multicolumn{2}{|l|}{$(-6.28)$} \\
\hline \multirow[t]{2}{*}{ Intercept } & $1.286^{*}$ & $-0.260^{* * *}$ & $1.069^{*}$ & $-0.318^{* * *}$ & 0.692 & $-0.323^{* * *}$ \\
\hline & $(1.95)$ & $(-6.81)$ & $(1.78)$ & $(-7.99)$ & $(1.14)$ & $(-8.31)$ \\
\hline Industry fixed effects & Yes & Yes & Yes & Yes & Yes & Yes \\
\hline Year fixed effects & Yes & Yes & Yes & Yes & Yes & Yes \\
\hline Obs. & 7902 & 7902 & 7584 & 7584 & 7584 & 7584 \\
\hline Pseudo $R^{2} /$ Adjusted $R^{2}$ & 0.159 & 0.170 & 0.160 & 0.173 & 0.166 & 0.173 \\
\hline
\end{tabular}

This table presents the results of treatment effect regressions that control for potential endogeneity of reversal causality. Using Heckman's two-step procedure, the non-family chair dummy is instrumented by the regional divorce rate (Divorce rate) and the logarithm of total meal income of local catering firms (Meal income). In the first-stage Probit model with the non-familychair dummy as the dependent variable, instruments are included as independent variables in addition to those controls in the main regression. We then exclude instruments but add the inverse Mills ratio (Lambda) derived from the first stage into the second-stage OLS regression model. Columns 1, 3 and 5 report the results of the first-stage Probit regressions. Results from the second stage of the endogenous treatment effect model are shown in columns 2, 4 and 6 . All regressions include year and industry dummies, but their coefficients are not reported for the sake of brevity. See the Appendix for detailed descriptions of the variables. The values in parentheses are standard errors that are robust to heteroskedasticity and clustered at the firm level. Asterisks denote statistical significance at the $1 \%(* * *), 5 \%\left({ }^{* *}\right)$ or $10 \%(*)$ level, respectively 
Table 8 Two-stage least squares (2SLS) analysis for firm performance and chair identity

\begin{tabular}{|c|c|c|c|c|c|c|}
\hline & \multicolumn{2}{|l|}{ (1) } & \multicolumn{2}{|l|}{ (2) } & \multicolumn{2}{|l|}{ (3) } \\
\hline & First & Second & First & Second & First & Second \\
\hline \multirow[t]{2}{*}{ NFChair (instrumented) } & & $-0.053^{* * *}$ & & $-0.084^{* * *}$ & & $-0.068^{* * *}$ \\
\hline & & $(-2.73)$ & & $(-3.66)$ & & $(-4.04)$ \\
\hline \multirow[t]{2}{*}{ Size } & $-0.015^{* *}$ & $0.015^{* * *}$ & -0.009 & $0.015^{* * *}$ & -0.011 & $0.015^{* * *}$ \\
\hline & $(-2.16)$ & $(12.50)$ & $(-1.26)$ & $(11.64)$ & $(-1.62)$ & $(12.19)$ \\
\hline \multirow[t]{2}{*}{ Leverage } & $0.106^{* * *}$ & $-0.033^{* * *}$ & $0.096^{* * *}$ & $-0.030^{* * *}$ & $0.098^{* * *}$ & $-0.032^{2 * *}$ \\
\hline & (6.49) & $(-9.14)$ & $(5.87)$ & $(-7.83)$ & (5.99) & $(-9.20)$ \\
\hline \multirow[t]{2}{*}{ MB } & $0.012^{* * *}$ & -0.000 & $0.011^{* * *}$ & -0.000 & $0.011^{* * *}$ & -0.000 \\
\hline & $(7.04)$ & $(-0.84)$ & $(6.47)$ & $(-0.14)$ & (6.38) & $(-0.66)$ \\
\hline \multirow[t]{2}{*}{ Board } & $-0.110^{* * *}$ & -0.004 & $-0.123^{* * *}$ & -0.010 & $-0.115^{* * *}$ & -0.008 \\
\hline & $(-3.97)$ & $(-0.78)$ & $(-4.26)$ & $(-1.59)$ & $(-4.01)$ & $(-1.37)$ \\
\hline \multirow[t]{2}{*}{ Independence } & $-0.425^{* * *}$ & $-0.032^{*}$ & $-0.514^{* * *}$ & $-0.057^{* *}$ & $-0.480^{* * *}$ & $-0.049^{* *}$ \\
\hline & $(-4.39)$ & $(-1.65)$ & $(-4.91)$ & $(-2.48)$ & $(-4.59)$ & $(-2.32)$ \\
\hline \multirow[t]{2}{*}{ Duality } & $-0.063^{* * *}$ & $-0.006^{* * *}$ & $-0.056^{* * *}$ & $-0.008^{* * *}$ & $-0.056^{* * *}$ & $-0.007^{* * *}$ \\
\hline & $(-6.09)$ & $(-2.63)$ & $(-5.32)$ & $(-3.14)$ & $(-5.32)$ & $(-3.04)$ \\
\hline \multirow[t]{2}{*}{ Top1 } & $-0.002^{* * *}$ & $0.001^{* * *}$ & $-0.002^{* * *}$ & $0.000^{* * *}$ & $-0.002^{* * *}$ & $0.000^{* * *}$ \\
\hline & $(-6.31)$ & (6.50) & $(-6.02)$ & $(4.96)$ & $(-6.03)$ & $(6.11)$ \\
\hline \multirow[t]{2}{*}{ Top25 } & $-0.004^{* * *}$ & $0.000^{* * *}$ & $-0.004^{* * *}$ & $0.000^{*}$ & $-0.004^{* * *}$ & $0.000^{* * *}$ \\
\hline & $(-9.18)$ & (3.29) & $(-8.68)$ & (1.93) & $(-8.44)$ & (2.91) \\
\hline \multirow[t]{2}{*}{ Institution } & $0.003^{* * *}$ & $0.002^{* * *}$ & $0.003^{* * *}$ & $0.002^{* * *}$ & $0.003^{* * *}$ & $0.002^{* * *}$ \\
\hline & (3.10) & (10.09) & (2.98) & (9.96) & (2.92) & (10.28) \\
\hline \multirow[t]{2}{*}{ Foreign } & -0.013 & 0.001 & 0.020 & 0.001 & 0.020 & 0.001 \\
\hline & $(-0.45)$ & $(0.30)$ & $(0.71)$ & $(0.21)$ & $(0.71)$ & $(0.23)$ \\
\hline \multirow[t]{2}{*}{ Tangibility } & $0.146^{* * *}$ & 0.001 & $0.140^{* * *}$ & 0.004 & $0.131^{* * *}$ & 0.002 \\
\hline & (3.92) & $(0.13)$ & (3.69) & (0.52) & (3.46) & $(0.22)$ \\
\hline \multirow[t]{2}{*}{ Firm age } & $0.010^{* * *}$ & 0.000 & $0.010^{* * *}$ & 0.001 & $0.010^{* * *}$ & 0.000 \\
\hline & $(9.09)$ & $(0.67)$ & $(9.20)$ & $(1.62)$ & $(9.03)$ & $(1.30)$ \\
\hline \multirow[t]{2}{*}{ CapEx } & $-0.622^{* * *}$ & -0.013 & $-0.652^{* * *}$ & $-0.041^{*}$ & $-0.648^{* * *}$ & -0.031 \\
\hline & $(-7.43)$ & $(-0.68)$ & $(-7.64)$ & $(-1.87)$ & $(-7.63)$ & $(-1.60)$ \\
\hline
\end{tabular}

Instrumental variables

Divorce rate

$0.007^{* * *}$

$0.005^{* * *}$

Meal income

$-0.036^{* * *}$

(7.16)

mexecen

$1.049^{* * *}$

$-0.261^{* * *}$

(-8.25)

$-0.030^{* * *}$

Industry fixed effect

$$
\text { (5.42) }
$$

(-6.41)

$0.943^{* * *}$

$-0.276^{* * *}$

(-6.71)

Year fixed effects

Yes

Yes

Obs.

F-statistics

Sargan chi-squared

Sargan $p$-value

This table presents the results of 2SLS instrumental variable regressions that control for potential endogeneity of reversal causality. We use Divorce rate and Meal income as instruments to identify chair identity in the first-stage and then regress the firm performance measure on the fitted values of NFChair and other controls. All regressions include year and industry dummies, but their coefficients are not reported for the sake of brevity. See the Appendix for detailed descriptions of the variables. At the bottom of the table, we also include the results from the weak instrument tests and overidentification tests. The values in parentheses are standard errors that are robust to heteroskedasticity and clustered at the firm level. Asterisks denote statistical significance at the $1 \%\left({ }^{* * *}\right), 5 \%\left({ }^{* *}\right)$ or $10 \%(*)$ level, respectively 
endogeneity. Overall, non-family chairs continue to have negative effects on firm performance after controlling for potential endogeneity, and the IV regression results confirm the direction of causality from the non-family-chair appointment to firm performance.

\section{Difference-in-difference analysis}

To alleviate the concern of omitted variables such as the invariant firm culture, we employ the difference-in-difference (DID) method to evaluate the impact of a non-family chair on firm performance. Specifically, we compare the difference in performance change before and after the appointment of a new chair between the two groups of firms with chair turnover. The treatment firms are those that have their chairs change from family to non-family members, while the control firms are continuously headed by non-family chairs. We define the sample for the DID analysis as firm-years surrounding the chair transition from 2 years before to 2 years after. ${ }^{11}$

Panel A of Table 9 reports the univariate tests of the chair transition. Among the treatment firms, firm performance decreases (with a negative sign - though the difference is not significant) after the chair turnover. Instead, the control group of firms experiencing chair turnover from a family chair to a non-family chair exhibit performance improvement after the chair transition. The increases in performance are 0.026 and 0.023 respectively, when we use the full sample of chair transitions or restrict our sample to years at the first chair transition; both are significant at the $5 \%$ level. It is worth noting that the DID estimates shown in the last column are both negative and statistically distinguishable from zero, which suggests that the performance increase from the chair transition is larger for the control firms than for the treatment group. In other words, the treatment group experiences relative losses in firm performance. The results from the multivariate regressions are presented in Panel B. We include three additional variables compared with the specifications in Table 4: Treat, an indicator of the group of firms which change from having a family member as board chair to having a non-family chair; Post, a dummy that takes the value of one for firm-years after the chair transition, and Treat $\times$ Post, the product of these two variables. The standard errors are robust and clustered at the firm level. Consistent with univariate tests, the coefficients of the interaction term (Treat $\times$ Post) are significantly negative, suggesting that firms indeed experience noticeable declines in performance when the chair transfers from a family member to an outsider. The results are similar if we use the industry-adjusted performance measure as the dependent variable or the alternative three-year window before and after the chair transition.

We also replicate the main regression of firm performance on the non-family-chair dummy in Table 4 by using the firm fixed effect model. In untabulated tests, we find that the coefficient of the non-family-chair dummy remains negative and strongly significant. Overall, the analyses support our previous finding: the employment of a chair from outside the controlling family has a negative effect on firm performance.

\section{Moderating effects of outside monitoring and family structure}

In this section, we investigate the conditions that impact the effects of a non-family chair on firm performance. As the appointment of a non-family chair reduces the costs 
Table 9 Difference-in-Difference (DID) analysis of performance changes

\begin{tabular}{cclc}
\hline \multicolumn{2}{c}{ Panel A: Univariate DID tests } & & \\
\multicolumn{2}{c}{ Treatment (Family-to-nonfamily) } & Control (Family-to-family) & DID (Treat-co \\
Full sample of chair transitions & & \\
Difference (after-before) & -0.013 & $0.023^{* *}$ & $-0.036^{* *}$ \\
& $(-1.14)$ & $(2.01)$ & $(-2.23)$ \\
& {$[170]$} & {$[165]$} & {$[335]$} \\
First chair transition event & & & \\
Difference (after-before) & -0.011 & $0.026^{* *}$ & $-0.037^{* *}$ \\
& $(-0.98)$ & $(2.10)$ & $(-2.20)$ \\
& {$[165]$} & {$[150]$} & {$[315]$}
\end{tabular}

Panel B: DID regressions of firm performance during chair transitions

\begin{tabular}{lll} 
& $(1)$ & $(2)$ \\
Treat*Post & Full sample of chair transitions & First chair transition \\
& $-0.031^{* *}$ & $-0.032^{* *}$ \\
Treat & $(-2.26)$ & $(-2.01)$ \\
& 0.018 & 0.019 \\
Post & $(1.23)$ & $(1.18)$ \\
& 0.022 & 0.027 \\
Intercept & $(1.61)$ & $(1.53)$ \\
& -0.287 & -0.338 \\
Other controls & $(-1.32)$ & $(-1.50)$ \\
Industry fixed effects & Yes & Yes \\
Year fixed effects & Yes & Yes \\
Obs. & 335 & Yes \\
Adjusted $R^{2}$ & 0.134 & 315 \\
\hline
\end{tabular}

This table presents the differences in performance changes before and after the chair transitions between non-familychair firms and family-chair firms. We use a five-year window for analysis - from two years before to two years after the chair transition. Panel A reports the univariate DID results for the full sample or the subsample of first chair turnovers. Numbers in parentheses are t-statistics, and in brackets are the number of observations. Panel B shows the DID regression results with control variables used in the main regression. We use a full sample of chair transitions in column 1 and use only the first chair transition event for each firm in column 2. All regressions include year and industry dummies, but their coefficients are not reported for the sake of brevity. See the Appendix for detailed descriptions of the variables. Asterisks denote statistical significance at the $1 \%\left({ }^{* *}\right), 5 \%(* *)$ or $10 \%(*)$ level, respectively

of reputation loss borne by families, the expropriation issues are expected to be severe in non-family-chair firms and to lead to low performance. Therefore, we examine whether the strength of external monitoring moderates the relationship between a non-family chair and firm performance, since outside monitoring increases a family's reputation concerns and thus mitigates their self-interested incentives (Anderson and Reeb 2003).

The proxies for outside monitoring come from government, analysts and the public. We use the index measuring the development of market intermediaries and the legal environment of Chinese provinces by Fan and Wang (2006) to indicate local institutional efficiency. ${ }^{12}$ This index has been used in many studies of China (Jiang et al. 2010; Li et al. 2011; Amit et al. 2015; Jiang et al. 2015). The higher the index, the better the minority shareholders are protected. ${ }^{13}$ Furthermore, as the number of analysts following the firm increases the transparency of firm operations, the incentive of the controlling shareholder to conduct tunneling is weakened. We also use the number of times the controllers are 
included on the Hurun China Rich List, an annual listing of China's wealthiest entrepreneurs or businessmen/businesswomen, as the proxy for media, public and government monitoring. ${ }^{14}$ The Rich List publishes detailed information about entrepreneurs such as their age, birth place and the major firms they control. After the publication of the Rich List, the media have shown great interest in uncovering negative news about billionaires and their companies (Hong 2004). Moreover, the authorities enforce regulations more strictly for the business people on the Rich List (Firth et al. 2014). Entrepreneurs and the listed firms are closely monitored after they are included on the Rich List.

According to studies on multiple large shareholders (Zwiebel 1995; Laeven and Levine 2008), large shareholders are less likely to be active in monitoring when the distribution of shareholdings is more diversified. We calculate the ownership dispersion by dividing the shares held by the controller over the sum of shares owned by the second to fifth largest shareholders. A lower ratio indicates a more balanced ownership structure. In this case, we expect that non-family-chair firms would be more likely to underperform family-chair firms when there are large shareholders with comparable ownerships than those with a leading controlling shareholder.

Finally, we examine the moderating effect of family size approximated by the enforcement of the one-child policy. The likelihood of family transitions affects the horizon of the family, the importance of family reputation and the intention to pursue family interests at the expense of minority shareholders. Similar to Cao et al. (2015), we use the one-child policy as a proxy for whether the controlling shareholders have a limited number of children and as a proxy for the "pool size" for a family successor. Specifically, we assume that the controllers born after 1960 have only one child, while others born prior to 1960 have multiple children. ${ }^{15}$

Table 10 reports the results of the moderating effects. As expected, the coefficients of the interaction terms between the non-family-chair dummy and the proxies for external monitoring are all significantly positive as shown in columns 1 to 3 . The findings suggest that outside monitoring mitigates the negative impact of a non-family chair on firm performance since the incentive for families to tunnel resources from the listed firm is weakened under strong supervision. Column 5 shows the impact of ownership structure on the relationship between the non-family chair and firm performance. The positive sign of the interaction term in column 4 supports the idea that, compared with those in firms with concentrated ownership structures, other large shareholders in firms with comparable ownerships are more likely to collude with the controlling shareholder to tunnel resources when a chair is not a family member. In column 5, the interaction variable between a non-family-chair dummy and the indicator of the one-child policy is statistically significant and negative, which suggests that the controlling shareholders care less about family reputation and have stronger incentives to tunnel resources in non-family-chair firms when the likelihood of family succession is lower. As shown, the effect of a non-family chair on firm performance is more pronounced when outside monitoring is weaker, when large shareholders are cooperative, and when family succession is less likely. The evidence supports the reputation hypothesis.

\section{Alternative explanations}

For the results so far, we attribute the lower performance of non-family-chair firms compared with those with family chairs to the weaker reputation concern and the stronger expropriation by the controlling families. In this section, we explore a few alternative explanations. 
Table 10 The moderating effects of outside monitoring and family size

\begin{tabular}{|c|c|c|c|c|c|}
\hline & (1) & (2) & (3) & (4) & (5) \\
\hline & $\begin{array}{l}\text { Institutional } \\
\text { development }\end{array}$ & $\begin{array}{l}\text { Analyst } \\
\text { coverage }\end{array}$ & $\begin{array}{l}\text { \# of times on } \\
\text { Hurun } \\
\text { China Rich List }\end{array}$ & $\begin{array}{l}\text { Ownership } \\
\text { balance }\end{array}$ & $\begin{array}{l}\text { One-child } \\
\text { policy }\end{array}$ \\
\hline \multirow[t]{2}{*}{ NFChair } & $-0.021^{* * *}$ & $-0.014^{* * *}$ & $-0.016^{* * *}$ & $-0.018^{* * *}$ & $-0.007^{*}$ \\
\hline & $(-3.81)$ & $(-4.29)$ & $(-4.55)$ & $(-5.39)$ & $(-1.87)$ \\
\hline \multirow[t]{2}{*}{ Setting } & 0.000 & $0.002^{* * *}$ & $-0.002^{* * *}$ & $-0.001^{* * *}$ & -0.002 \\
\hline & $(1.40)$ & $(14.58)$ & $(-3.06)$ & $(-3.81)$ & $(-0.90)$ \\
\hline \multirow[t]{2}{*}{ NFChair*Setting } & $0.001^{*}$ & $0.001^{* *}$ & $0.002^{*}$ & $0.001^{* *}$ & $-0.010^{*}$ \\
\hline & $(1.76)$ & (2.58) & $(1.85)$ & (2.35) & $(-1.80)$ \\
\hline \multirow[t]{2}{*}{ Size } & $0.016^{* * *}$ & $0.006^{* * *}$ & $0.018^{* * *}$ & $0.015^{* * *}$ & $0.016^{* * *}$ \\
\hline & (10.41) & (3.70) & (10.32) & (9.84) & $(10.34)$ \\
\hline \multirow[t]{2}{*}{ Leverage } & $-0.036^{* * *}$ & $-0.037^{* * *}$ & $-0.035^{* * *}$ & $-0.039^{* * *}$ & $-0.036^{* * *}$ \\
\hline & $(-4.37)$ & $(-4.46)$ & $(-4.17)$ & $(-4.63)$ & $(-4.10)$ \\
\hline \multirow[t]{2}{*}{$\mathrm{MB}$} & -0.001 & -0.001 & -0.001 & $-0.001^{*}$ & -0.001 \\
\hline & $(-1.31)$ & $(-1.32)$ & $(-1.38)$ & $(-1.72)$ & $(-1.15)$ \\
\hline \multirow[t]{2}{*}{ Board } & -0.000 & -0.000 & -0.000 & 0.001 & -0.000 \\
\hline & $(-0.01)$ & $(-0.04)$ & $(-0.07)$ & $(0.22)$ & $(-0.01)$ \\
\hline \multirow[t]{2}{*}{ Independence } & -0.012 & -0.006 & -0.012 & -0.012 & -0.014 \\
\hline & $(-0.52)$ & $(-0.28)$ & $(-0.54)$ & $(-0.53)$ & $(-0.61)$ \\
\hline \multirow[t]{2}{*}{ Duality } & -0.004 & $-0.005^{* *}$ & -0.004 & -0.003 & -0.003 \\
\hline & $(-1.62)$ & $(-2.14)$ & $(-1.58)$ & $(-1.56)$ & $(-1.16)$ \\
\hline \multirow[t]{2}{*}{ Top1 } & $0.001^{* * *}$ & $0.000^{* * *}$ & $0.001^{* * *}$ & $0.001^{* * *}$ & $0.001^{* * *}$ \\
\hline & $(6.91)$ & (5.68) & $(7.83)$ & $(6.54)$ & (6.83) \\
\hline \multirow[t]{2}{*}{ Top25 } & $0.001^{* * *}$ & $0.000^{* * *}$ & $0.001^{* * *}$ & & $0.001^{* * *}$ \\
\hline & $(5.07)$ & (3.08) & $(5.41)$ & & (5.08) \\
\hline \multirow[t]{2}{*}{ Institution } & $0.002^{* * *}$ & $0.001^{* * *}$ & $0.002^{* * *}$ & $0.002^{* * *}$ & $0.002^{* * *}$ \\
\hline & $(8.22)$ & $(3.61)$ & (8.13) & $(8.77)$ & (8.24) \\
\hline \multirow[t]{2}{*}{ Foreign } & 0.001 & 0.007 & 0.002 & 0.003 & 0.002 \\
\hline & $(0.13)$ & $(0.98)$ & $(0.23)$ & $(0.41)$ & $(0.25)$ \\
\hline \multirow[t]{2}{*}{ Tangibility } & -0.005 & 0.001 & -0.004 & -0.010 & -0.008 \\
\hline & $(-0.55)$ & $(0.16)$ & $(-0.46)$ & $(-1.11)$ & $(-0.86)$ \\
\hline \multirow[t]{2}{*}{ Firm age } & -0.000 & 0.000 & -0.000 & $-0.000^{* *}$ & -0.000 \\
\hline & $(-0.90)$ & $(0.57)$ & $(-0.83)$ & $(-2.02)$ & $(-1.20)$ \\
\hline \multirow[t]{2}{*}{ CapEx } & 0.013 & -0.018 & 0.009 & 0.019 & 0.009 \\
\hline & $(0.78)$ & $(-1.13)$ & $(0.57)$ & $(1.15)$ & $(0.52)$ \\
\hline \multirow[t]{2}{*}{ Intercept } & $-0.292^{* * *}$ & $-0.130^{* * *}$ & $-0.345^{* * *}$ & $-0.263^{* * *}$ & $-0.295^{* * *}$ \\
\hline & $(-8.33)$ & $(-3.61)$ & $(-8.84)$ & $(-7.64)$ & $(-8.27)$ \\
\hline Industry fixed effects & Yes & Yes & Yes & Yes & Yes \\
\hline Year fixed effects & Yes & Yes & Yes & Yes & Yes \\
\hline Obs. & 7902 & 7844 & 7902 & 7902 & 7676 \\
\hline Adjusted $R^{2}$ & 0.170 & 0.203 & 0.170 & 0.165 & 0.167 \\
\hline
\end{tabular}

This table presents the results of the regressions which examine the moderating effects of outside monitoring and the family attribute on the relation between having a non-family chair and firm performance. We use the development of the institutional environment, the number of analysts following, the number of times the controller was included on the Hurun China Rich List, the balance of ownership structure, and the number of children in the family. Institutional development is indicated by the index measuring the development of market intermediaries and the legal environment at the province level. We use the one-child policy to proxy whether the controlling shareholders have a limited number of children. All regressions include year and industry dummies, but their coefficients are not reported for the sake of brevity. See the Appendix for detailed descriptions of the variables. The values in parentheses are standard errors that are robust to heteroskedasticity and clustered at the firm level. Asterisks denote statistical significance at the $1 \%$ (***), $5 \%\left({ }^{*}\right)$ or $10 \%(*)$ level, respectively 
First, entrepreneurs are considered as a special group of people who possess valuable skills in firm management and knowledge which are hard to pass on (Morck et al. 1988; Villalonga and Amit 2006; Fahlenbrach 2009). However, through formal meetings in the company or informal communication at the dinner table, members of the controlling family have more opportunities to be in contact with the entrepreneurs and may be more likely to share similar values than non-family members. In this case, the underperformance of non-family-chair firms could be due to the insufficiency of managerial talents possessed by non-family chairs. Meanwhile, as the country of origin of Confucian culture, the degree of trust outside the family in China is low (Xu et al. 2015). Combined with weak investor protection and a far from mature labor market for professional managers (Jiang and Kim 2015), non-family chairs may be suboptimal choices for successors compared with family members, as indicated by the principal-agent perspective (Jensen and Meckling 1976). We first use the chair's formal education as a proxy for managerial capabilities and further examine the difference in investment efficiency between non-family-chair and family-chair firms. Contrary to our expectations, the univariate test suggests that non-family chairs on average receive significantly higher degrees than their counterparts (3.455 vs. 3.372 ). The lack of significance in the interaction variable (NFChair $\times$ CapEx) in column 1 of Table 11 also suggests that family chairs do not have superior talent in investment compared with non-family chairs. These results indicate that management quality and principal-agent conflicts cannot fully explain the underperformance of non-family-chair firms.

Second, the underperformance of non-family-chair firms might be driven by the lower amount of time and energy allocated to monitoring the agents by the controlling families in those firms. To test this hypothesis, we employ two proxies: the number of firms that the controller controls at the same time (Numfirm) and the controller's age (Agecon). Under this approach, firms with busier or older controlling shareholders are monitored less by the families and perform worse (see columns 2 to 5). But controlling the Numfirm or Agecon variable in the regression does not reduce the significance of the estimates of the non-family-chair dummy (see columns 2 and 4). The coefficient of NFChair $\times$ Numfirm in column 3 is not statistically significant, suggesting that the differences in firm performance exists regardless of the number of firms under control. Contrary to our prediction, the interaction term (NFChair $\times$ Agecon) is statistically significant and positive as shown in column 5 . The controllers in non-family-chair firms are also more than 1 year younger than those in family-chair firms. The results imply that the view of busy or old controlling shareholders deteriorating non-family-chair firms is not accurate. Thus, our results are not driven by the impact from the chair side or differences in attention that families pay to the listed firm.

Third, previous studies have shown that the divergence of cash flow rights and control rights has a significantly negative effect on firm performance as the controlling shareholders might pursue private interests at the expense of minority shareholders (e.g., Claessens et al. 2002; Faccio and Lang 2002; Fan and Wong 2002; Villalonga and Amit 2006; Amit et al. 2015; Liu et al. 2015). ${ }^{16}$ It is possible that the controlling families in non-family-chair firms have higher excess control rights than those in family-chair firms, and this difference may result in performance gaps between the groups. We include the excess control rights dummy (Excon) as an additional explanatory variable in column 6 and its interaction with a non-family-chair dummy in column 7. The results show that the coefficients of NFChair are still negative and significant, and the interaction term is not statistically significant. Hence, chair identity plays an additional role in determining firm 
Table 11 Tests of alternative explanations

\begin{tabular}{|c|c|c|c|c|c|c|c|c|}
\hline & \multirow{2}{*}{$\begin{array}{l}\text { Investment } \\
\text { efficiency } \\
\text { (1) }\end{array}$} & \multicolumn{2}{|c|}{$\begin{array}{l}\text { Number of firms } \\
\text { controlled }\end{array}$} & \multicolumn{2}{|l|}{$\begin{array}{l}\text { Age of the } \\
\text { controller }\end{array}$} & \multicolumn{2}{|c|}{$\begin{array}{l}\text { Excess control } \\
\text { rights }\end{array}$} & \multirow{2}{*}{$\begin{array}{l}\text { Share } \\
\text { reform } \\
\text { (8) }\end{array}$} \\
\hline & & $(2)$ & (3) & (4) & (5) & (6) & (7) & \\
\hline \multirow[t]{2}{*}{ NFChair } & $-0.011^{* * *}$ & $-0.013^{* * *}$ & $-0.021^{* *}$ & $-0.013^{* * *}$ & $-0.168^{* * *}$ & $-0.013^{* * *}$ & $-0.011^{*}$ & $-0.017^{*}$ \\
\hline & $(-2.99)$ & $(-4.54)$ & $(-2.93)$ & $(-4.50)$ & $(-2.75)$ & $(-4.55)$ & $(-1.69)$ & $(-1.78)$ \\
\hline \multirow[t]{2}{*}{ NFChairxCapEx } & 0.048 & & & & & & & \\
\hline & $(1.17)$ & & & & & & & \\
\hline \multirow[t]{2}{*}{ Numfirm } & & -0.003 & $-0.008^{* *}$ & & & & & \\
\hline & & $(-0.98)$ & $(-2.40)$ & & & & & \\
\hline \multirow[t]{2}{*}{ NFChair*Numfirm } & & & 0.007 & & & & & \\
\hline & & & $(1.39)$ & & & & & \\
\hline \multirow[t]{2}{*}{ Agecon } & & & & $0.020^{* * *}$ & 0.008 & & & \\
\hline & & & & $(2.91)$ & (1.03) & & & \\
\hline \multirow[t]{2}{*}{ NFChair*Agecon } & & & & & $0.040^{* *}$ & & & \\
\hline & & & & & $(2.57)$ & & & \\
\hline \multirow[t]{2}{*}{ Excon } & & & & & & $-0.007^{* * *}$ & $-0.007^{* * *}$ & \\
\hline & & & & & & $(-2.80)$ & $(-2.77)$ & \\
\hline \multirow[t]{2}{*}{ NFChair Excon } & & & & & & & -0.002 & \\
\hline & & & & & & & $(-0.24)$ & \\
\hline \multirow[t]{2}{*}{ Finish } & & & & & & & & 0.006 \\
\hline & & & & & & & & $(0.26)$ \\
\hline \multirow[t]{2}{*}{ NFChair*Finish } & & & & & & & & 0.002 \\
\hline & & & & & & & & $(0.21)$ \\
\hline \multirow[t]{2}{*}{ Intercept } & $-0.311^{* * *}$ & $-0.307^{* * *}$ & $-0.303^{* * *}$ & $-0.364^{* * *}$ & $-0.313^{* * *}$ & $-0.283^{* * *}$ & $-0.283^{* * *}$ & $-0.588^{* * *}$ \\
\hline & $(-8.64)$ & $(-8.90)$ & $(-8.80)$ & $(-8.51)$ & $(-6.75)$ & $(-8.28)$ & $(-8.26)$ & $(-6.86)$ \\
\hline Other controls & Yes & Yes & Yes & Yes & Yes & Yes & Yes & Yes \\
\hline $\begin{array}{l}\text { Industry fixed } \\
\text { effects }\end{array}$ & Yes & Yes & Yes & Yes & Yes & Yes & Yes & Yes \\
\hline Year fixed effects & Yes & Yes & Yes & Yes & Yes & Yes & Yes & Yes \\
\hline Obs. & 7532 & 7902 & 7902 & 7818 & 7818 & 7682 & 7682 & 1643 \\
\hline Adjusted $R^{2}$ & 0.176 & 0.169 & 0.169 & 0.167 & 0.168 & 0.170 & 0.170 & 0.148 \\
\hline
\end{tabular}

This table presents the regression results when we study the effect of a non-family chair after controlling for alternative explanations. In columns 1 to 5 , we take the differences in management ability (e.g., investment efficiency) and the efforts that a chair makes (the number of firms controlled and the entrepreneurs' age) into consideration. In columns 6 to 8 , we estimate regressions with traditional factors (the divergence of control rights and cash flow rights and the liquidity concern) as additional explanatory variables. All regressions include year and industry dummies, but their coefficients are not reported for the sake of brevity. See the Appendix for detailed descriptions of the variables. The values in parentheses are standard errors that are robust to heteroskedasticity and clustered at the firm level. Asterisks denote statistical significance at the $1 \%\left({ }^{* * *}\right), 5 \%\left(^{* *}\right)$ or $10 \%\left(^{*}\right)$ level, respectively

performance beyond the divergence of control rights and cash flow rights held by the controlling families.

Finally, earlier studies have found that firms with higher stock liquidity experience less severe expropriation problems while using China's split-share structure reform (SSSR) as an exogenous shock (Li et al. 2011; Chen et al. 2012) ${ }^{17}$ The share reform aligns the interests of the controlling shareholder and minority shareholders to some extent as it converts the non-tradable shares held by the controlling shareholder into freely tradable shares. It is possible that the shares of the non-family-chair firms are less liquid in the stock market compared with those of family-chair firms. To address this issue, we examine the impact of a 
non-family chair on firm performance using a subsample of firms that experience SSSR and compare the changes in performance for both types of firms. We use a time window of 3 years before and after the reform, and we define the dummy variable, Finish, equal to 1 for years when the share reform is completed (and 0 otherwise). We predict that the interaction variable (NFChair $\times$ Finish) would be significantly positive if our results were caused by stock illiquidity. Column 8 shows the results of the difference-in-difference test. The coefficient of NFChair retains its sign and significance, while NFChair $\times$ Finish is not statistically significant. Therefore, the difference in stock liquidity is not a major concern.

Overall, the consistent significance and negative sign of estimates on the non-family-chair dummy and the lack of statistical significance for most interaction variables suggest that our findings cannot be explained by the factors mentioned above.

\section{Conclusion}

Despite the critical role of family firms in economic growth, relatively equivalent attention from researchers has not been paid to them - especially those in emerging markets with weak investor protection. In this paper, we investigate the impact of family involvement as a board chair by using a sample of Chinese listed firms from 1999 to 2014. We find that the appointment of a chair who has no apparent family ties with the controlling family deteriorates firm performance. The result is robust to a variety of model specifications and a series of methods to address the potential endogeneity issues. Further analyses show that the negative effect of a non-family chair is more pronounced when the listed firm is under weaker outside monitoring, and the controlling families care less about business longevity. Results from these tests support our hypothesis that the interest conflicts between the controlling families and minority shareholders are more severe in non-family-chair firms due to the lower costs of reputation loss borne by the families. We also confirm that the reputation view is most appropriate and consistent with the empirical evidence.

Our paper could be viewed as providing straight and detailed evidence that non-family chairs hamper firm performance, and - more importantly - the conditions under which the negative impact of non-family-chair appointments could be reduced. Our findings are consistent with Anderson and Reeb (2003), which implies that outside monitoring might be a good method for minimizing family misbehavior in markets such as East Asia. We also find support for arguments by Chen et al. (2015), suggesting that families are more likely to undertake self-interested behaviors such as using related-party loan guarantees in business groups when they are able to escape blame. Our paper contributes to the literature on how family involvement affects firm performance and the literature on the influence of board chairs in firms.

Based on our research, investors should be cautious about board chair appointment decisions in family firms. Sitting in a relatively opaque position behind the "scapegoat" of non-family chairs, the controlling families might extract more private benefits at the sacrifice of other stakeholders. Moreover, the implications of our results might be applied to other settings in which the controlling families have a strong influence on firm decisions while investor protection is weak. Although we document the significant and negative effect of a non-family chair on firm performance, our findings are probably conservative since we only focus on the role of the board chair. With detailed 
information provided on the family side such as family structure, future research may examine how various types of family involvement (e.g., leadership structure, generation effect) affect corporate decisions in different ways.

\section{Endnotes}

${ }^{1}$ We begin our sample period in 1999 because most financial data are not available until then. As the number of observations in 1999 is only 11, the results hold if they are excluded from our sample. Though information about the ultimate controller has been required to be shown in annual reports since 2003, we are able to gather this information in earlier years when firms voluntarily disclose this information.

${ }^{2}$ For example, the database lists all potential controllers when the listed firms are controlled by more than one person, or it only presents the controlling family rather than the identity of the ultimate controller. A single ultimate controller for each firm is finally identified according to certain selection conditions. We define the ultimate controller as the one who is the single controller (or when there are multiple, unrelated controllers reported, the one who is the largest shareholder). When the listed firm is controlled by a family, we set the ultimate controller as the person who holds at least $10 \%$ more shares than other family members or, when family ownership is diffused, the one who ranks the highest in the company hierarchy (chair, co-chair, directors, CEO, division managers, etc.).

${ }^{3}$ Since the control variables are lagged in the regression, the sample period for our analyses begins with 2000 .

${ }^{4}$ There are several potential explanations for this sharp decline in 2008 and the continuous decease in the following years. First, though China did not suffer much from the economic crisis in 2008 compared with other countries, firms experienced an economic recession, and entrepreneurs were likely to take over and manage their firms. Second, a few small, young companies issued IPOs since the establishment of the Growth Enterprise Market in 2009, and most of them are headed by the entrepreneurs themselves. When we only focus on firms that are listed on the main boards, the ratio of firms led by a non-family chair has remained stable at about $42.57 \%$ since 2008 (although it falls significantly in 2007).

${ }^{5}$ Though return on equity $(R O E)$ is also a prevalent performance measure in the literature, we do not use it because this measure is often manipulated in China. In 1999, the China Securities Regulatory Commission (CSRC) issued a regulation concerning the performance of firms that want to undertake a seasoned equity offering. It requires firms to achieve a minimum average $R O E$ of $10 \%$ in the most recent three years, and ROE should not be lower than $6 \%$ in any given year. Then, in 2002, the CSRC raised the minimum $R O E$ to $10 \%$ in the nearest accounting year in addition to requiring a minimum average $R O E$ in the prior three years.

${ }^{6}$ Firms with foreign investors refer to firms that issue B shares, which were first tradable only for foreigners and additionally for mainland investors after 2001, or H shares which are shares of mainland companies listed on the Hong Kong Stock Exchange. Compared with mainland investors who are mostly speculative, foreign investors are considered to be valuable investors who play an important role in shaping firm policies. Meanwhile, listing on a more mature stock 
market with strict information disclosure requirements might increase corporate governance and firm performance.

${ }^{7}$ Not surprisingly, the variable for independence does not change much both across and within firms at about one-third since most firms introduce independent directors only to meet regulation requirements.

${ }^{8} \mathrm{~A}$ correlation with an absolute value of 0.7 or higher would suggest a collinearity issue.

${ }^{9}$ Results are similar when we use OROA, ROS and OROS as the dependent variables.

${ }^{10}$ Considering that the local institutional environment might influence firm performance, we run additional regressions of those instruments on firm performance with other controls. The results show that all three instruments are not statistically significant, which confirms that our instruments satisfy the exclusion condition to some extent.

${ }^{11}$ We choose two years before and two years after the chair transition as our event window because of the balance between a longer period for the large sample size and a shorter period without the effects of the other events. Before the construction of the sample firms, we require that the firm have no missing financial data in the transition period of interest.

${ }^{12}$ The comprehensive index of market development collected from Fan and Wang (2006) include five dimensions: the relationship between the government and the market, the development of non-state sectors, the development of product markets, the development of factor markets and the development of market intermediaries and the legal institutional environment. As the core of our analysis is investor protection, we only use the corresponding sub-index of institutional efficiency rather than the entire marketization index.

${ }^{13}$ In an untabulated test, we also use the index of investment climate from the World Bank's (2006) ranking of 30 provinces in China following Amit et al. (2015) as the alternative measure of institutional efficiency. The nine provinces categorized as having high institutional efficiency are: Jiangsu, Shanghai, Zhejiang, Fujian, Guangdong, Shandong, Beijing, Tianjin and Hebei. The other 21 provinces - excluding Tibet -are categorized as having low institutional efficiency.

${ }^{14}$ The Hurun China Rich List originally was compiled in 1999 with only 50 entrepreneurs, while it covered more than 1200 entrepreneurs in 2014. The computation base of the fortunes of the Rich List entrepreneurs comes from both publicly traded and private firms.

${ }^{15}$ We choose 1960 as the cutoff for two reasons. First, the one-child policy was formally enacted in 1980, though only the Communist Party members or League members were initially subjected to it. The marriage law effected in 1980 required that men should be at least 20 years old to get married. Second, the one-child policy became a strictly enforced national policy in the constitution in 1982, while the new marriage law at that time provided an increase in the legal minimum age of marriage for men (age 22). We use another cutoff of 1956 to address the concern of late marriage or late childbirth, and the results are unchanged.

${ }^{16}$ Following previous research, we compute the control rights owned by the controlling shareholder as the sum of the weakest links in the control chains and cash flow rights as the sum of the products of ownership stakes along the chains.

${ }^{17}$ We conduct the analyses following previous research - though the exogeneity of the split share structure reform is suspicious. 


\section{Appendix}

Table 12 Variable descriptions

\begin{tabular}{|c|c|}
\hline Variable & Description \\
\hline $\mathrm{ROA}$ & Net income divided by total assets. \\
\hline OROA & Operating income divided by total assets. \\
\hline ROS & Net income divided by total sales. \\
\hline OROS & Operating income divided by total sales. \\
\hline NFChair & $\begin{array}{l}\text { The indicator of the relationship between the controller and the board chair, which } \\
\text { equals } 1 \text { if the chair is not a family member (and } 0 \text { otherwise). }\end{array}$ \\
\hline Size & The natural logarithm of a firm's market capitalization. \\
\hline MB & The ratio of the market-to-book value of equity. \\
\hline Leverage & Total liabilities divided by total assets. \\
\hline Board & The natural logarithm of the number of directors on the board. \\
\hline Independence & The percentage of independent directors on the board. \\
\hline Duality & A dummy variable, which equals 1 if the chair is also the CEO (and 0 otherwise). \\
\hline Top1 & The percentage of shares held by the largest shareholder. \\
\hline Top25 & The sum of percentages of shares held by the second to fifth largest shareholders. \\
\hline Institution & The percentage of shares held by institutional investors. \\
\hline Foreign & A dummy variable, which equals 1 if there are foreign investors (and 0 otherwise). \\
\hline Tangibility & The ratio of fixed assets to total assets. \\
\hline Firm age & The number of years since a firm's founding. \\
\hline CapEx & $\begin{array}{l}\text { The ratio of the difference between the cash paid and received from the treatment of } \\
\text { fixed, intangible and other long-term assets to total assets. }\end{array}$ \\
\hline Meal income & The logarithm of total meal income of catering firms at the province level. \\
\hline Divorce rate & $\begin{array}{l}\text { The number of divorce registrations per 10,000 people in the province where a family } \\
\text { firm is located. }\end{array}$ \\
\hline $\begin{array}{l}\text { Institutional } \\
\text { development }\end{array}$ & $\begin{array}{l}\text { An index measuring the development of market intermediaries and the legal } \\
\text { environment. }\end{array}$ \\
\hline Analyst coverage & The number of analysts following a listed firm. \\
\hline Hurun times & The number of times the controller is included on the Hurun China Rich List. \\
\hline Ownership balance & The ratio of the Top 1 to the Top 25. \\
\hline One-child policy & $\begin{array}{l}\text { A dummy variable, which equals } 1 \text { if the controller is born in a year later than } \\
1960 \text { (and } 0 \text { otherwise). }\end{array}$ \\
\hline NFCEO & $\begin{array}{l}\text { A dummy variable, which is equal to } 1 \text { if the CEO is a non-family member and ( } 0 \\
\text { otherwise). }\end{array}$ \\
\hline Chair_Age & The logarithm of a chair's age. \\
\hline Chair_Education & $\begin{array}{l}\text { The education level received by the board chair which ranges from } 1 \text { (lower than senior } \\
\text { high school) to } 5 \text { (Ph.D. degree and above). }\end{array}$ \\
\hline Chair_Gender & A dummy variable, which equals 1 if the board chair is female (and 0 otherwise). \\
\hline Numfirm & The number of firms that the controller controls in a given year. \\
\hline Agecon & The logarithm of the controller's age. \\
\hline Excon & $\begin{array}{l}\text { The difference between the ownership rights and the control rights held by the } \\
\text { controlling family. }\end{array}$ \\
\hline Finish & $\begin{array}{l}\text { A dummy variable, which equals } 1 \text { if the firm has completed the split share structure } \\
\text { reform. }\end{array}$ \\
\hline
\end{tabular}

\section{Acknowledgements}

Fuxiu Jiang acknowledges the financial support of the fund for building world-class universities (disciplines) of Renmin University of China (Project No. 16XNL007). All remaining errors and omissions are our own. 


\section{Funding}

The research is supported by fund for building world-class universities (disciplines) of Renmin University of China (Project No. 16XNL007).

Availability of data and material

Please contact author for data requests.

\section{Authors' contributions}

FJ conceived the study, joined the research design, and helped to draft the manuscript. XZ designed the research, undertook the empirical analysis, and drafted the manuscript. WT helped draft the manuscript. All authors read and approved the final manuscript.

\section{Authors' information}

FJ is a professor of Finance at School of Business, Renmin University of China.

$X Z$ is a Ph.D. student in Finance at School of Business, Renmin University of China.

WT is a postdoctoral fellow at School of Business, Renmin University of China.

\section{Competing interests}

The authors declare that they have no competing interests.

\section{Publisher's Note}

Springer Nature remains neutral with regard to jurisdictional claims in published maps and institutional affiliations.

Received: 30 May 2018 Accepted: 7 September 2018

Published online: 21 September 2018

\section{References}

Amit, R., Ding, Y., Villalonga, B., \& Zhang, H. (2015). The role of institutional development in the prevalence and performance of entrepreneur and family-controlled firms. Journal of Corporate Finance, 31, 284-305.

Anderson, R. C., \& Reeb, D. M. (2003). Founding-family ownership and firm performance: Evidence from the S\&P 500. The Journal of Finance, 58(3), 1301-1327.

Andres, C. (2008). Large shareholders and firm performance-an empirical examination of founding-family ownership. Journal of Corporate Finance, 14(4), 431-445.

Bae, K.-H., Kang, J.-K., \& Wang, J. (2011). Employee treatment and firm leverage: A test of the stakeholder theory of capital structure. Journal of Financial Economics, 100(1), 130-153.

Bennedsen, M., Nielsen, K. M., Perez-Gonzalez, F., \& Wolfenzon, D. (2007). Inside the family firm: The role of families in succession decisions and performance. The Quarterly Journal of Economics, 122(2), 647-691.

Berrone, P., Cruz, C., Gomez-Mejia, L. R., \& Larraza-Kintana, M. (2010). Socioemotional wealth and corporate responses to institutional pressures: Do family-controlled firms pollute less? Administrative Science Quarterly, 55(1), 82-113.

Bertrand, M., Johnson, S., Samphantharak, K., \& Schoar, A. (2008). Mixing family with business: A study of Thai business groups and the families behind them. Journal of Financial Economics, 88(3), 466-498.

Burkart, M., Panunzi, F., \& Shleifer, A. (2003). Family firms. The Journal of Finance, 58(5), 2167-2201.

Cai, D., Luo, J., \& Wan, D. (2012). Family CEOs: Do they benefit firm performance in China? Asia Pacific Journal of Management, 29(4), 923-947.

Cao, J., Cumming, D., \& Wang, X. (2015). One-child policy and family firms in China. Journal of Corporate Finance, 33, 317-329.

Chahine, S., \& Goergen, M. (2013). The effects of management-board ties on IPO performance. Journal of Corporate Finance, $21,153-179$.

Chang, S. J., \& Shim, J. (2014). When does transitioning from family to professional management improve firm performance? Strategic Management Journal, 36(9), 1297-1316.

Chen, Q., Chen, X., Schipper, K., Xu, Y. X., \& Xue, J. (2012). The sensitivity of corporate cash holdings to corporate governance. Review of Financial Studies, 25(12), 3610-3644

Chen, X., Arnoldi, J., \& Na, C. (2015). Governance structure and related party loan guarantees: The case of Chinese family business groups. Management and Organization Review, 11(4), 599-619.

Chua, J. H., Chrisman, J. J., Steier, L. P., \& Rau, S. B. (2012). Sources of heterogeneity in family firms: An introduction. Entrepreneurship Theory and Practice, 36(6), 1103-1113.

Claessens, S., Djankov, S., Fan, J. P. H., \& Lang, L. H. P. (2002). Disentangling the incentive and entrenchment effects of large shareholdings. The Journal of Finance, 57(6), 2741-2771.

Claessens, S., Djankov, S., \& Lang, L. H. (2000). The separation of ownership and control in east Asian corporations. Journal of Financial Economics, 58(1-2), 81-112.

Cucculelli, M., \& Micucci, G. (2008). Family succession and firm performance: Evidence from Italian family firms. Journal of Corporate Finance, 14(1), 17-31.

Deephouse, D. L., \& Jaskiewicz, P. (2013). Do family firms have better reputations than non-family firms? An integration of socioemotional wealth and social identity theories. Journal of Management Studies, 50(3), 337-360.

Dyck, A., Volchkova, N., \& Zingales, L. (2008). The corporate governance role of the media: Evidence from Russia. The Journal of Finance, 63(3), 1093-1135.

Dyer, W. G., \& Whetten, D. A. (2006). Family firms and social responsibility: Preliminary evidence from the S\&P 500 Entrepreneurship Theory Practice, 30(6), 785-802.

Elster, J. (1989). Social norms and economic theory. Journal of Economic Perspectives, 3(4), 99-117.

Faccio, M., \& Lang, L. H. P. (2002). The ultimate ownership of Western European corporations. Journal of Financial Economics, 65(3), 365-395. 
Fahlenbrach, R. (2009). Founder-CEOs, investment decisions, and stock market performance. Journal of Financial and Quantitative Analysis, 44(2), 439-466.

Fan, G., \& Wang, X. (2006). In: The report on the relative process of marketization of regions in China. Beijing: The Economic Science Press.

Fan, J. P., \& Wong, T. J. (2002). Corporate ownership structure and the informativeness of accounting earnings in East Asia. Journal of Accounting and Economics, 33(3), 401-425.

Filatotchev, I., Lien, Y.-C., \& Piesse, J. (2005). Corporate governance and performance in publicly listed, family-controlled firms: Evidence from Taiwan. Asia Pacific Journal of Management, 22(3), 257-283.

Firth, M., He, X., Rui, O. M., \& Xiao, T. (2014). Paragon or pariah? The consequences of being conspicuously rich in China's new economy. Journal of Corporate Finance, 29, 430-448.

Heckman, J. J. (1979). Sample selection bias as a specification error. Econometrica, 47, 153-161.

Hong, Z. (2004). Mapping the evolution and transformation of the new private entrepreneurs in China. Journal of Chinese Political Science, 9(1), 23-42.

Imbens, G. W., \& Wooldridge, J. M. (2009). Recent developments in the econometrics of program evaluation. Journal of Economic Literature, 47(1), 5-86.

Isakov, D., \& Weisskopf, J.-P. (2014). Are founding families special blockholders? An investigation of controlling shareholder influence on firm performance. Journal of Banking and Finance, 41, 1-16.

Jameson, M., Prevost, A., \& Puthenpurackal, J. (2014). Controlling shareholders, board structure, and firm performance: Evidence from India. Journal of Corporate Finance, 27, 1-20.

Jensen, M. C., \& Meckling, W. H. (1976). Theory of the firm: Managerial behavior, agency costs and ownership structure. Journal of Financial Economics, 3(4), 305-360.

Jiang, F., \& Kim, K. A. (2015). Corporate governance in China: A modern perspective. Journal of Corporate Finance, 32, 190-216.

Jiang, G. H., Lee, C. M. C., \& Yue, H. (2010). Tunneling through intercorporate loans: The China experience. Journal of Financial Economics, 98(1), 1-20.

Jiang, G. H., Rao, P. G., \& Yue, H. (2015). Tunneling through non-operational fund occupancy: An investigation based on officially identified activities. Journal of Corporate Finance, 32, 295-311.

Jiang, Y., \& Peng, M. W. (2011). Principal-principal conflicts during crisis. Asia Pacific Journal of Management, 28(4), 683-696.

Karpoff, J. M., Scott Lee, D., \& Martin, G. S. (2008). The consequences to managers for financial misrepresentation. Journal of Financial Economics, 88(2), 193-215.

Krause, R. (2017). Being the CEO's boss: An examination of board chair orientations. Strategic Management Journal, 38(3), 697-713.

Krause, R., Semadeni, M., \& Withers, M. C. (2016). That special someone: When the board views its chair as a resource. Strategic Management Journal, 37(9), 1990-2002.

La Porta, R., Lopez-de-Silanes, F., \& Shleifer, A. (1999). Corporate ownership around the world. The Journal of Finance, 54(2), 471-517.

Laeven, L., \& Levine, R. (2008). Complex ownership structures and corporate valuations. Review of Financial Studies, 21(2), 579-604.

Leitterstorf, M. P., \& Rau, S. B. (2014). Socioemotional wealth and IPO underpricing of family firms. Strategic Management Journal, 35(5), 751-760.

Li, K., Wang, T., Cheung, Y. L., \& Jiang, P. (2011). Privatization and risk sharing: Evidence from the split share structure reform in China. Review of Financial Studies, 24(7), 2499-2525.

Liu, Q., Luo, T., \& Tian, G. G. (2015). Family control and corporate cash holdings: Evidence from China. Journal of Corporate Finance, 31, 220-245.

Luo, X. R., \& Chung, C. N. (2013). Filling or abusing the institutional void? Ownership and management control of public family businesses in an emerging market. Organization Science, 24(2), 591-613.

Ma, L., Ma, S., \& Tian, G. (2013). Political connections, founder-managers, and their impact on tunneling in China's listed firms. Pacific-Basin Finance Journal, 24, 312-339.

Martin, G., Campbell, J. T., \& Gomez-Mejia, L. (2016). Family control, socioemotional wealth and earnings management in publicly traded firms. Journal of Business Ethics, 133(3), 453-469.

Maury, B. (2006). Family ownership and firm performance: Empirical evidence from Western European corporations. Journal of Corporate Finance, 12(2), 321-341.

McConaughy, D. L., Walker, M. C., Henderson Jr., G. V., \& Mishra, C. S. (1998). Founding family controlled firms: Efficiency and value. Review of Financial Economics, 7(1), 1-19.

Miller, D., Le Breton-Miller, I., Lester, R. H., \& Cannella Jr., A. A. (2007). Are family firms really superior performers? Journal of Corporate Finance, 13(5), 829-858.

Morck, R., Shleifer, A., \& Vishny, R. W. (1988). Management ownership and market valuation: An empirical analysis. Journal of Financial Economics, 20, 293-315.

Morck, R., Stangeland, D., \& Yeung, B. (2000). Inherited wealth, corporate control, and economic growth the Canadian disease? In: Concentrated Corporate Ownership. Chicago: University of Chicago Press, pp. 319-372.

Mullins, W., \& Schoar, A. (2016). How do CEOs see their roles? Management philosophies and styles in family and non-family firms. Journal of Financial Economics, 119(1), 24-43.

Pamuk, A. (2000). Informal institutional arrangements in credit, land markets and infrastructure delivery in Trinidad. International Journal of Urban and Regional Research, 24(2), 379-496.

Park, S. H., \& Luo, Y. (2001). Guanxi and organizational dynamics: Organizational networking in Chinese firms. Strategic Management Journal, 22(5), 455-477.

Pérez-González, F. (2006). Inherited control and firm performance. The American Economic Review, 96(5), 1559-1588.

Putnam, R. (1993). The prosperous community: Social capital and public life. The American Prospect, 4(13), 35-42.

Rentfrow, P.J. (2014). Geographical psychology: Exploring the interaction of environment and behavior. Washington, DC: American Psychological Association.

Rosenbaum, P. R., \& Rubin, D. B. (1983). The central role of the propensity score in observational studies for causal effects. Biometrika, 70(1), 41-55.

Smith, B. F., \& Amoako-Adu, B. (1999). Management succession and financial performance of family controlled firms. Journal of Corporate Finance, 5(4), 341-368. 
Sraer, D., \& Thesmar, D. (2007). Performance and behavior of family firms: Evidence from the French stock market. Journal of the European Economic Association, 5(4), 709-751.

Villalonga, B., \& Amit, R. (2006). How do family ownership, control and management affect firm value? Journal of Financial Economics, 80(2), 385-417.

Withers, M. C., \& Fitza, M. A. (2017). Do board chairs matter? The influence of board chairs on firm performance. Strategic Management Journal, 38(6), 1343-1355.

Wooldridge, J. M. (2002). Econometric analysis of cross section and panel data. Cambridge and London: MIT Press.

Xu, N., Yuan, Q., Jiang, X., \& Chan, K. C. (2015). Founder's political connections, second generation involvement, and family firm performance: Evidence from China. Journal of Corporate Finance, 33, 243-259.

Young, M. N., Peng, M. W., Ahlstrom, D., Bruton, G. D., \& Jiang, Y. (2008). Corporate governance in emerging economies: A review of the principal-principal perspective. Journal of Management Studies, 45(1), 196-220.

Zattoni, A., Gnan, L., \& Huse, M. (2015). Does family involvement influence firm performance? Exploring the mediating effects of board processes and tasks. Journal of Management, 41(4), 1214-1243.

Zellweger, T. M., Nason, R. S., Nordqvist, M., \& Brush, C. G. (2013). Why do family firms strive for nonfinancial goals? An organizational identity perspective. Entrepreneurship Theory Practices, 37(2), 229-248.

Zwiebel, J. (1995). Block investment and partial benefits of corporate control. Review of Economic Studies, 62(2), 161-185.

Submit your manuscript to a SpringerOpen ${ }^{\circ}$ journal and benefit from:

- Convenient online submission

- Rigorous peer review

- Open access: articles freely available online

- High visibility within the field

- Retaining the copyright to your article

Submit your next manuscript at $\boldsymbol{\nabla}$ springeropen.com 